\title{
THE CILIUM AS A KEY TO THE STRUCTURE OF CONTRACTILE PROTOPLASM.
}

\author{
BY \\ O. I. DELLINGER. \\ Contribution from the Biological Laboratory of Clark Cnitersity.
}

TABLE OF CONTENTS.

PAGE

Introduction: Statement of Problem $\ldots \ldots \ldots \ldots \ldots \ldots \ldots \ldots \ldots$ 172

Historical: Literature on the Structure of Protoplasm.......... 173

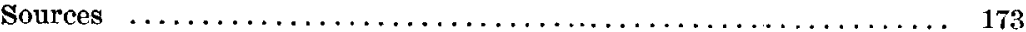

Early views.

Contractile protoplasm reticular or fibrillar............... 17:

Englemann's Inotagmas .............................. 178

Strasburger's Kino-and Trophoplasm .................... 178

Leydig's Hyloplasm $\ldots \ldots \ldots \ldots \ldots \ldots \ldots \ldots \ldots \ldots \ldots \ldots$

Objections to the Contractile theory . . . . . . . . . . . . . . . . 180

Protoplasm a complex fluid or foam ...................... 180

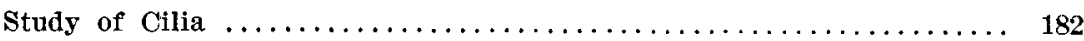

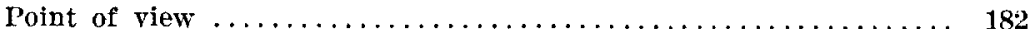

Observations on the finer structure of cilia............... 183

Theories of the structure of cilia $\ldots \ldots \ldots \ldots \ldots \ldots \ldots$

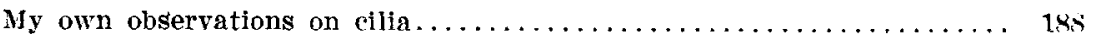

Comparative study of the effect of reagents.............. 18;

Other worlz; Fischer, Hardy, and others............ 185

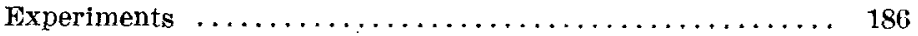

Conclusions $\ldots \ldots \ldots \ldots \ldots \ldots \ldots \ldots \ldots \ldots$

Structure revealed by teasing. . . . . . . . . . . . . . . . . 189

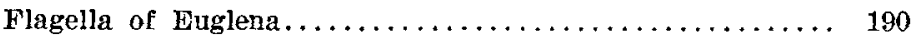

Cilia of Stylonychia $\ldots \ldots \ldots \ldots \ldots \ldots \ldots \ldots \ldots \ldots \ldots$

Application of Methods to Other Contractile Tissues............. 193

Protozoa.

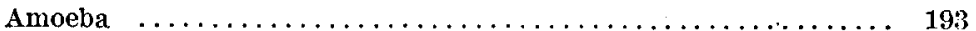

Actinosphaerium $\ldots \ldots \ldots \ldots \ldots \ldots \ldots \ldots \ldots \ldots \ldots \ldots \ldots \ldots$

Stentor $\ldots \ldots \ldots \ldots \ldots \ldots \ldots \ldots \ldots \ldots \ldots \ldots \ldots \ldots \ldots \ldots$

Smooth muscle $\ldots \ldots \ldots \ldots \ldots \ldots \ldots \ldots \ldots \ldots \ldots \ldots \ldots \ldots$

Stem of vorticella.

Striped muscle.

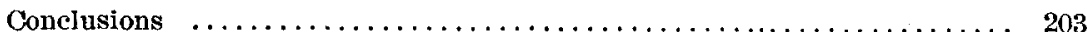

The Journal of Morphology,-Vol, XX, No. 2. 


\section{Introduction: Statement of Problem.}

A complete title for this paper would be: The Cilium studied comparatively as a test of microscopical methods and a key to the structure of contractile protoplasm.

The attempts of recent investigators to resolve the activities of contractile structures into phenomena due to alterations in the surface tension of a complex fluid are proving as unsatisfactory as the older attempts to identify contractility with chemical and electrical processes. Those who approached the problem from this standpoint-Berthold, Quinckne, Bütschli, Rhumbler, Jensen and others-used the Amoeba with its activities as "Ausgangspunkt" for their researches. Unfortunately they did not determine the real character of the movements here, and, therefore, their theories of protoplasmic movement based on the supposed activities of the protoplasm of the Amoeba have little value. The work of Jennings (1904) and Dellinger (1906) has shown their position to be untenable.

Instead of seeking in the movements of the Amoeba for a key to the structure of contractile protoplasm, the present study turns to the cilium. Here we find contractile tissue, microscopically speaking, in its simplest form. As the cilia are outgrowths of the cell protoplasm, there is every reason to suppose that exactly similar structures may exist within the cell body. Until we have applied to the protoplasm of the cell the methods best adapted to preserve and demonstrate the character of cilia, we are not justified in appealing to indefinite and undemonstrable fluids to do the work of solids.

The investigation falls naturally into two parts. The first is concerned with the best methods of preserving and demonstrating the structure of cilia. The second is the application of these methods to contractile protoplasm as represented in the Protozoa, smooth muscle and striped musele.

I wish to acknowledge my indebtedness to Dr. C. F. Hodge, under whose direction the work has been done, for many helpful suggestions and criticisms; to Mr. L. N. Wilson, Librarian of the University, for aid in securing the literature, and to Dr. F. N. Duncan for permission to use part of his unpublished manuscript. 
Historical: Literature on the Structure of Protoplasm. Sources.

Reference will be given to special papers at the end of this work. There have been a number of comprehensive treatises devoted to different phases of the subject that should, however, be mentioned at this time.

1. Haller, "Elementa Physiologiae," Vol. IV, P. 514, gives a summary of the old theories of muscular contraction.

2. Herman, in the "Handbuch der Physiologie," reviews the theories from Haller's time up to 1879.

3. Cornoy, "La Biologie Cellulaire," gives an excellent review of the conceptions of protoplasm between 1665 and 1865 .

4. Bütschli, in his "Mikroskopische Schäume und das Protoplasma," gives an exhaustive review of the works on protoplasmic structure between 1860 and 1892 .

5. The theories of the structure of protoplasm are briefly summed up by Delage, "L'Heredite," 1903, pp. 23-33.

6. Davis, "Studies on the plant cell," covers the literature on the botanical side.

7. Flemming, in Merkel and Bonnet's Ergebnisse, Vols. II, III. IV, V and VI, gives the recent literature on the cell. Few papers of any import are omitted from his exhaustive treatment.

8. The literature on the cilium is admirably brought together by Putter in Asher and Spiro's Ergebnisse, Vol. II, No. 2, pp. 1-102.

9. Fischer, "Fixirung, Farbung and Bau des Protoplasmas," presents a criticism of the methods of cytology.

10. Heidenhain in Asher and Spiro's Ergebnisse, Vols. VIII and $X$, gives a full review of the literature on the muscle.

EarLy Views.

Protoplasm Without Visible Organization and Contractile. ${ }^{1}$

The first to postulate an internal framework to explain the movements of protoplasm was Brücke (1861). Previous observers and

The first conceptions of the nature of protoplasm were developed between if65, the date of the discovery of the cell by Robert Hooke, and 1839 , the date of Schwann's publication. We find it variously spoken of at this time as "matière ou substance organisatrice, matière formatrice, mati- 
most of the investigators of his time conceived protoplasm to be semifluid, viscid substance without visible organization. Among those who did much to establish this view are to be mentioned Max Schultz (1855-1863), Haeckel (1862) and Kühne (1864). The first two worked with the protozoa, Schultz especially with the Rhizopods, Haeckel with the Radiolarians, Kühne upon protoplasm. All writers were, however, united in ascribing to protoplasm or "Sarcode" the property of contractility. Under these circumstances one is not surprised that they sought in this fundamental property the explanation of all protoplasmic movements. Although many investigators have opposed this view, it has had at all times a goodly number of supporters and at present seems to be gaining in favor. Besides Schultz, Haeckel and Kühne, referred to above, we should mention Reichert (1863), Brücke (1861), Cienkowsky (1863) and de Bary (1862 and 1864) as early holding this conception.

If protoplasmic movements were to be explained on the basis of contractility of protoplasm, it was necessary to assume some organization for this substance. Although Brücke did postulate a contractile

ère germinale," etc. (Cornoy, 1884, p. 176). In 1835, Dujardin designated it as "sarcode" in the infusoria. With Schleiden it was, "Schleim." (Beiträge zur Phytogenesis. Miuller's Arch., 1838). The advances in microscopical anatomy during the years 1839 and 1840 gives Purkinje the credit of first using the term "protoplasm." Later, von Mohl ("On the Movements of Sap in the Interior of the Cell," Bot. Zeitung, 1846, p. 73) says, "The remainder of the cell is more or less densely filled with an opaque, viscid fluid of a white color, having granules intermingled in it, which fluid I call protoplasm."

The first to speak definitely of its properties was Dujardin. (Sur les Organismes inferieurs, Ann. Sc. Nat. 1835, p. 367.) In speaking of the sarcode he says, "Je propose de nommer ainsi ce que d'autres observateurs ont appéle une gelée vivant, cette matière glutineuse, diaphane, insoluble dans l'eau, se contractant en masses globuleuses. . . enfin se trouvant dans tous les animaux inferieurs interposée aux autres élements de structure." Between 1840 and 1865 the work of Schultz, Haeckel, Williamson, and among the botanists, Naegeli, Gohn, de Bary, Cienkowsky, and many others did much to give us clear conceptions of protoplasm. Cornoy sums up the general notion of its properties at the end of this period in the following sentence: "Une masse diaphane, semi-liquide et visqueuse, extensible mais non elastique, homogène, c'est-a-dire sans structure, sans organisation visible, parsemée de nombreux granules et enfin essentiellement douée d'irritabilitê et de contractilité." 
framework, which was the beginning of our reticular theory of the structure of protoplasm, most of the investigators of his time were simply content to refer in a general way to contractility as an ultimate factor, not attempting further analysis.

\section{Contractile Protoplasm Reticular or Fibrillar.}

Although the early writers were united in ascribing to protoplasm the property of contractility, it was first with Briicke that this contractile substance took on organization. It is not very clear just what his views were, but it is evident he thought that protoplasm was made up of a firm, contractile reticulum bathed in a fluid. Two years later Cienkowsky assumed a similar structure for the plasmodia of the myxomycetes.

It was perfectly natural, therefore, for Heitzmann when he found a reticular framework in the protoplasm of Amoebae and the white corpuscles of a number of animals (Flusskeckers, Tritons and Menschen) to ascribe to this reticulum contractility, anl to see in it an explanation of all protoplasmic movements. (Heitzmann, 1873.) He also agreed with Brücke and Cienkowsky in that he thought this reticulum bathed by a non-contractile fluid. Bütschli (1892, p. 105) questions Heitzmann's observations, and thinks we should attach little value to them. Hower this may be, it is quite possible he came much nearer divining the true structural character of protoplasm than did Bütschli himself. A large number of investigators since Heitzmann's time have, in the main, agreed with him that protoplasm has a reticular or fibrillar structure and that it is the framework or fibrillae that is contractile, referring all phenomena of movement (locomotion, change of form, ciliary movement, etc.) to these structures. ${ }^{2} \Lambda$ mong those holding this point of view are to be

${ }^{2}$ We can trace back to an early date observations on the reticular or fibrillar structure of certain cells. Thus for the muscle, according to Heindenhain, we find Lauth (1834), Schwann (1839), Henle (1841) and Holst (1846), speaking of "feinere und parallele Fibrillen." Later the extensive works of Wagner (1863) and Rouget (1863) in the Gastropods, Nematodes, Lumbricus, and various higher animals, brought out beautiful fibrillae in the smooth muscles of these forms. Heidenhain has recently gone over the literature covering the muscle and $I$ refer the reader to him for further history of this subject. 
mentioned Schmitz (1880), Reinke and Rodewald (1881-2), Cornoy

The fibrillar nature of certain nervous elements was first called to our attention by Remak (1837, 1843 and 1844). This doctrine was further developed by the works of Remak (1852), Stilling (1856), Leydig (1862 and 1864), Walter (1863), Deiters (1865), Arnold (1865 and 1866), Schultz (1868 and 1871), and Frommann (1867 and later), Bütschli.

Ciliated and non-ciliated epithelial cells were also shown by the work of Friedrich (1859), Eberth and Marchi (1866), Stuart (1867), Arnold (1875), Eimer (1877), and Nussbaum (1877) to contain fibrous or striated structures, Englemann (1880) for the ciliated epithelium and Leydig (1856), Henle (1866), Pflüger (1866, 1869, 1871) and Heldenhain (1868 and 1875) for the non-ciliated epithelial cells, describe similar structures. Frommann was first to advance the theory that some such structure is universally present in protoplasm, and, according to Bitschli, to him is due the credit of suggesting a possible reticular structure for protoplasm.

${ }^{3}$ Schmitz made his observations on plant tissues that were killed in a saturated solution of picric acid. He is convinced of the reticular nature of protoplasm and disputes the interpretation sometimes given that reticular structures are coagula.

In the years 1878 and 1879 Klein came forward in two publications as a supporter of the reticular structure of protoplasn. According to him cilla may be a continuation of fibrils within the cell.

Reinke and Rodewald and later Reinke and Katschmar, working with Aethalium septicum, expressed themselves as favoring the net-like structure of protoplasm. Their method was (somewhat) unique and deserves more attention than it has received. They subjected cakes of the plant to pressure and succeeded in pressing out about 66 per cent. of the fluid. From this they concluded that what remained behind was the substance of the framework. This framework is arranged in a spongy reticulum and is contractile. The fluid "Enchylema" fills the intertrabecular spaces and is kept from escaping from them by an enveloping layer of the same substance as the framework. Reinke's views are much more fully developed later (1899 and 1905). He argues very strongly against the conception of the active protoplasm being of a fluid nature and his comparison "fluid oars of a boat to flagelle" is exactly to the point. Movements are always due, according to him, to the contraction of protoplasmic fibers.

The following quotation from Cornoy gives his point of view. "On peut admettre que le reticulum est seul doué d'irritabilité et de contractilité. C'est donc lui qui préside aux movements physiques, l'enchylema demeurant passif, ou a pu pres, dans cette categorie de phenomenes." It is thus seen that he thinks the protoplasm organized into a definite network, his reticulum, which is bathed in a fluid, the "Enchylema." of these the reticulum alone is active. His reticulum corresponds to the "mitom" of Flemming and the "protoplasma" of Kupffer.

Rabl (1869) held the view that the systems of rays found in connection 
with cell division are contractile fibrillae. These fibrillae arise from the reticulum of the protoplasm, during division, by the breaking down of the cross connections. After division they return to the reticular condition. by anastomosing.

Van Beneden (1876 and 1883) held that the protoplasm contained a contractile reticulum and that it was a modification of this that formed the asters in ova.

Apathy (1891) holds to the fibrillar structure for nerves and muscles. He supports his views by later investigations.

Ballowitz, through numerous investigations between 1880 and 1890 , gave very strong support to the fibrillar theory. Working with the spermatozoa he found evidence that convinced him of the fibrillar nature of contractile protoplasm. He believes that wherever we have contractility, fibrillae are to be found.

To go on through the list of contributions favoring this theory would take too much space. I will mention, however, some of the more recent papers bearing on this conception.

Schenck (1897 and 1900) came forward as an opponent to the fluid theory of protoplasm and as an advocate of fibrillar protoplasm. He thinks that Verworn's contractile fluids are not sufficient to explain protoplasmic movements and that contractile protoplasm (in the amoeba as well as elsewhere) "muss eine bestimmte structur haben, darf nicht als Flüssigkeit angesehen werden." And at another place "die contractile substanz fest ist."

The drawings of Arnold (1898) show beautiful fibrills in a large number of cells. He holds that this is the true structural character of protoplasm.

Allen (1903) working with the dividing pollen mother-cells of Larix holds that the fibers of the spindle arise from fibrills already present in the cell. That these fibers are contractile and that they control the activities of the cell. He argues against the view that they are precipitations as the result of killing.

Parker (1905) sees no reason why cilia might not be fibrillar and believes that their activities are best explained on the basis of such a structure.

Kunstler (1906) shows a beantiful reticular network in bacteria.

Hartmann (1906) thinks the active contractile part of protoplasm is fibrillar.

Duncan, working in this laboratory, has come to the conclusion (held by a number of writers) that the contractile elements in smooth muscle are fibrillar. Although he has not published his work the examination of a large number of forms has already been made and in every case he is able to demonstrate such structures.

In two investigations from this laboratory on the Amoeba, one published jointly with Dr. C. F. Hodge, the author is of the opinion that the movements of this form are only to be explained by the presence of a contractile framework and the last paper (Functions and Structures in A. proteus) collects the evidence for such structure. 
(1884-5-6), Ballowitz (1884 and later, 1888 and 1890), Rabl (1889), Schneider (1891 and later), Klein (1878 and 1879), Apathy (1891), and, more recently, Heitzmann (1894), Schenk (1897 and 1900), Arnold (1898), Allen (1903), Schneider (1903 and 1905), Reinke (1905), Parker (1905), Dellinger (1906), Hodge and Dellinger (unpublished), etc.

Although in recent years the results of many investigations have been opposed to this theory of the structure of protoplasm, the last two researches just mentioned have taken away much of the foundation on which opposition was based, and there is little doubt that it will prove nearer correct than any developed to take its place.

\section{Englemann's Inotagmas.}

A modification of the fibrillar theory was brought forward by Englemann in 1868 and further developed by him in 1879 and ' 80. According to him, 'protoplasm is an aggregate of minute contractile and "reizbar Formelemente." The phenomena of movement are the result of the change of form of these minute elements. Englemann names these contractile elements "Inotagmen." He thinks of them as molecular in size, spherical in form when contracted, and threadlike when at rest. The reasons for these assumptions are: First, that protoplasm in however small masses takes on a spherical form when contracted. Second, that when relaxed protoplasm shows often fine fibrillar striations and is, in its finest division in contractile structures, a "langgestreckte Form." Contraction is brought about by a change of turgidity, as the element would probably shorten with an increased turgidity and would stretch out again after giving off fluid.

\section{Strasburger's Kinoplasm and Trophoplasm.}

Strasburger (1892 and later) and many other botanists who have followed him divide protoplasm into two substances, his kinoplasm and trophoplasm. Of these the kinoplasm is active, entering into the formation of the fibrillae of the spindle and other active organs of the cell, such as the cilia, centrospheres, centrosomes and the cell membranes, while the trophoplasm is nutritive. The above classification implies a physiological difference in the two substances. 
According to Davis (1904, p. 712), the kinoplasm is homogeneous. in structure, either minutely granular or consisting of delicate fibrillae composed of very small granules placed end to end. Its homogeneous character is shown in the cell membranes, while the fibrous condition appears during cell activity and then disappears. On page 449 Davis says: "Kinoplasm runs through cycles in which the structure passes from a granular condition to a fibrillar and back again into a granular state." He admits that the fibrillae may not disappear, but simply be arranged in a closely packed network which is invisible under the microscope. All protoplasmic movements are due to the contraction of the kinoplasmic fibrillae. Although there is much about the kinoplasmic structure that is not understood, there is much in this theory of the structure of protoplasm that is attractive.

$$
\text { Hyaloplasm Active, Spongioplasm Inert. }
$$

One of the most peculiar theories developed to explain protoplasmic movements appeared in the year 1883. In this theory Brass (1883 and '84) and, soon after, Leydig (1885) exactly reverse the conception of the adherents of the reticular theory. Instead of the reticulum, the spongioplasm, according to these two writers, it is the fluid part, the hyaloplasm, that is contractile. In its activities is to be found an explanation of all protoplasmic movements. Few investigators have been inclined toward Leydig's hypothesis. Rhode (1890 and '91), Griesbach (1891) and Schäfer (1887, '91, '93 and 1904) about complete the list. Schäfer's views have been criticized by Bütschli (1892) and recently by Putter (1903), especially in its application to the cilium. Although Schäfer (1904) answers Putter's criticism, we find little in his discussion that warrants us in accepting his view. Recent investigations seem to prove conclusively that his position is untenable.

Schäfer's view may be summed up briefly as follows: Protoplasm is composed of two distinct substances, spongioplasm and hyaloplasm. "Spongioplasm has a reticular or sponge-like arrangement, an affinity for staining fluids, is firmer than hyaloplasm, but, perhaps not actually solid, and is in all probability highly extensible and elastic. Hyaloplasm, on the other hand, is structureless, has little or no affinity for stains and is highly labile and fluent. It is by the active flowing of 
the hyaloplasm, not by the contraction of the spongioplasm (as conceived by Cornoy), that the movements of cells are produced. Of the two substances, the hyaloplasm is the more active, the spongioplasm the more inert. The spongioplasm forms, in fact, a sort of framework supporting the hyaloplasm and into which, under the influence of stimuli, the hyaloplasm becomes wholly withdrawn" (Schäfer "On the Structure of Amoeboid Protoplasm," 1891, p. 195).

\section{Objections to the Contraction Theory.}

Observations, principally on the movements of the protoplasm in Amoebae and in plant cells, caused many observers to reject the contraction theory of the movements of protoplasm. In an advancing Amoeba the supposed currents which gave rise to the objections to contractility as a cause of protoplasmic movement were those beginning at the point of advance and extending backward. Wallich (1863) and Bütschli (1873) for Amoebae, and Hofmeister (1865 and '67) for the plant cell called attention to such currents. Since then many investigators have either thought they observed or else have assumed the presence of surface currents of this kind and have based their theories of protoplasmic movement on them.

Among those who took this standpoint were Hofmeister (1865 and 1867), Bütschli (1873), Quincke (1870 and later), Berthold (1872), and more recently Bütschli (1892), Rhumbler (1898, 1902, '03, '04 and '05), Gurwitsch (1904) and many others.

Unfortunately for the adherents of these theories, the recent investigations of Jennings (1904) and Dellinger (1906) have shown that the backward currents do not exist. It further appears that the real character of the movements in the Amoeba was not at all divined.

\section{Protoplasm a Complex Fluid.}

Berthold, Quincke, Schwartz, Rhumbler and others.

Although the doctrine of the fluid nature of protoplasm fell much into discredit during the seventies, it was taken up again in the eighties by a number of investigators.

Thus, Berthold, in his work published in 1886, came forward with arguments in favor of this conception which was universally 
held earlier. He did not, however, try to support it by direct proof, but laid it down, rather, as a hypothesis upon which to base his observations and speculations upon the structure and movements of protoplasm. According to him, protoplasm is an emulsion; that is, it is a mixture of two or more complex fluids ("Der Plasmakörper in seiner Gesammtheit als eine Emulsion von mehr oder weniger flüssiger Consistenz aufzufassen ist." (Berthold 1886, p. 64.)

Quincke (1870 and later) also held that protoplasm was a fluid, but after Bütschli's publication seemed to favor the foam theory. It was from Quincke that Bütschli got the idea of foanss which figure so prominently in his conceptions of protoplasm, but Quincke does not seem to have made the application of his foams to protoplasm until after Bütschli published.

Schwartz, another writer of this period (1897), seems to hold to the view of protoplasm as fluid, but, as Bütschli points out, it is difficult to understand just what his position is.

In recent years Verworn, Rhumbler, Jensen, Loeb, Gurwitch and many others have supported this view.

\section{BüTSChLI's SchüUme.}

Very early Bütschli, as has been noted above, objected to the contraction theory of protoplasmic movements, and in 1887 we find him advocating the fluid nature of the endosare of the Infusoria. Later (1892) he came out with a definite theory of the structure of protoplasm. According to him, the key to its structure is to be found in the microseopic oil-foams. The first fifty-seven pages are given up to the investigation of foams of different kinds. After an extensive study of the protoplasm of a large number of protozoa, of bacteria and of cells of many animal tissues, he concludes that its structure corresponds to that of the minutest microscopic foams. ("Nach meiner Auffassung entsprach der Aufbau des Plasmas den microskopischen Schaümen mit dem Untersehied, dass der Wabeninhalt gewöhnlicher Schäume hingeg€n eine wässerige Flüssigkeit sei." Bütschli, p. 3.) In the application of this conception to the explanation of protoplasmic movements he admits that, while it is satisfactory for amoeboid movement in the strict sense, modifications of it, especially 
the formation of the fine pseudopods of many "Sarcodina," find no explanation. (Bütschli, p. 198.) He suggests (p. 208) that muscular contraction may possibly be explained by the above hypothesis. The fibrils are there composed of a row of alveoli instead of being simple threads.

Since Biitschli's publication many observers have described protoplasm as a "Schaum." Thus, Andrews (1897), after a most extensive microscopic study of living protoplasm, decides that all the phenomena observed finds an explanation in Bütschli's Schaumstructure. Crato, in 1892, '95 and '96, finds the foam structure to hold for plant protoplasm. Erlanger (1897) expresses himself in favor of this theory. Degen (1905), after a series of investigations on the action of the contractile vacuole, is of the opinion that protoplasm is alveolar. The alveoli of his photographs, it seems, however, might be interpreted as meshes of a reticulum.

\section{Stuny of Ciris. \\ Point of View.}

A number of eminent investigators, Bütschli, Rhumbler, Jensen and others, have taken Verworn's standpoint, that "Die lebendige Substanz der rhizopodoiden Zelle mit ihrer Bewegung muss Ausgangspunkt für die Untersuchungen der Contractionserscheinung sein. Es heisst die Lösung des Contractionsproblems unnöthig erschweren, wenn man die Behandlung bei der quergestreiften Muskelzelle beginnt, wo die Differenzirung der lebendigen Substanz und ihre einseitige Anpassung an eine bestimmte Leistung ihren höchsten Entwicklungsgrad und ihre grösste Complication erreicht hat," and have approached the problem from this point of view. Yet the out. come of their investigations in complex fluids and microscopic foams has been unsatisfactory and has led to widespread confusion of our notions of contractile structures. For pure contractile tissue, micro. scopically speaking, our simplest structure is the cilium. Here, with the protoplasm accessible for experiments with all kinds of reagents, if anywhere, we should find the key to the structure of contractile protoplasm. If, in applying the methods for the demonstration of cilia to the protoplasm of the cell, structural elements are demon- 
strated, we may assume that these structures are real. It is from this point of view that the present investigation is pursued.

\section{Finer Structure of Cilia.}

"Ueber den feineren Bau aller genannten Organellen sind die Angaben überaus spärlich, die meisten Beobachter sahen nichts als hyalines Plasma" (Putter, 1903, p. 15). This is a fair statement of recent views. Although a study of ciliary action has led to certain fairly well-founded conclusions as to their probable structure, few direct observations of their finer anatomy have been made.

Englemann (1881, p. 541) points out that all large cilia, ciliary membranes, etc., are made up of fine fibrils. These fibrils correspond to those of all contractile structures.

Kliennenberg (1886) took the ground that the large "Geiseln der Wimperringe (bei Lopadorhynchus, Polycha) aus 20 bis 30 Cilien bestehen" (Putter).

Jensen (1887) figures, for the tail of sperms, fibrils that were brought out by pressure on the cover glass. Judging from his drawings the fibrillar structure is very evident.

Ballowitz (1886 and later), in a series of contributions to the structure of spermatozoa, gives some strong evidence for fibrillar structure in these organoids. In another paper (1890) he holds that contractile tissues, wherever found, are fibrillar. There is no doubt from his drawings that this is true, at least in the sperms.

Schuberg (1891) describes the "Zusammensetzung der Membranellen" of Stentor coeruleus and bursaria and of some hypotrichous infusorias. They consist, according to him, of two "Reihen" of fibrils.

Stevens (1901) asserts that the aboral membrane of Licnophora macfarlandii, Stevens, consists of fine long cilia, which are visible in the living animal under high magnification. (Putter.)

\section{Theories of the Structure of Cilia.}

Although there are a few direct observations on the finer anatomy of cilia, a number of theories of their probable structure have been advanced. These are admirably summed up by Putter, pages 27-29.

They are, in brief: First, that the cilia are lifeless processes attached to the cell. They are somewhat stiff and are moved by active 
elements in the cell body. That is, they are "Bewegbar, nicht beweglich." This was the conception of the earliest observers and has been recently revived by Benda (1891). Although it has at all times had occasional supporters, Stuart ${ }^{-1}$ (1867), Nussbaum (1877), Claparedes (1875) and Kraft (1890), it has not, as a rule, appealed to investigators.

Second, that cilia are hollow elastic sheaths into which a fluid is injected and withdrawn. This is the hypothesis advanced by Schäfer in 1891 and supported by him recently against an attack by Putter. So far as I know, it has found practically no support among investigators, most of them agreeing with Parker that there is little in recent work to justify it. In fact, the continued activity of cilia after complete isolation indicates that they contain within themselves their own contractile material.

Third, that cilia are complex fluids. This is the view of Verworn (1890 and later), also of Jensen. This conception has been criticized, Schenke (1890), in which criticism he gives the reasons why contractile substance cannot be fluid. So far as cilia are concerned, Reinke possibly expressed the objections to this view best when he said: "Als flüssig oder halbflüssig können diese Geisseln unmöglich gelten. Sie wären dann so wenig imstande, die mechanische Arbeit der Fortbewegung der Spore zu leisten wie est möglich ist, ein Boot zu bewegen mit Rudern die aus einer Flüssigkeit bestehen."

Fourth, that cilia have a fibrillar structure and that the movements are due to the contraction of these fibrils. The fibrils may be only temporary arrangements of the molecules of an otherwise homogeneous substance. This is Putter's view. He thinks himself forced to it by lack of structure in the flagellum. I do not think his position is well taken, and if, as will be shown later in this paper, the flagella are really fibrillar, he has no ground for it whatever.

In Englemann's theory, first advocated by him in 1868 and devel-

"Stuart bases his view on observations made on ciliated cells of "Aolidenlarven." He saw running through the cells parallel fibers some of which went to the nucleus. During cell activity, he observed that when the cilia were in motion the nucleus was also affected, and concluded that the structures in question were contractile fibers by which the cilia and nucleus were moved. 
oped further in 1879 , the fibers are permanent structures. Cilia are, according to him, composed of fine elements, "Inotagmen," which in their resting condition are fibril like and when contracted are more or less rounded. They are arranged with their long axis parallel to that of the cilium. Parker (1905) has expressed himself as in favor of the fibrillar hypothesis, and thinks it "the most consistent thus far advanced as an explanation of the more usual types of ciliary movement." He does not agree in any way with Putter's objections, and suggests that even in the apparently homogeneous flagella there may be fibrillae.

Ballowitz (1886, '88 and '90), Jensen (1887) and others conceive the fibrillae as running the full length of the cilia. They have gatlered much evidence which supports this view.

\section{Effect of Killing Reagents on Ciuia.}

\section{Introduction.}

Although many writers have dealt with the effects of killing reagents on protoplasm, Berthold (1886), Fischer (1894 and 1899), Bütschli (1892), Hardy (1899), Tellyesniczky (1898), Wasitlewski (1899) and others, none so far as I have known have approached the question from the standpoint of visible structural elements of the living tissue. They have, rather, dealt with structures that appear after the application of the reagent. For that reason there has always been a question as to the reality of such elements. In selecting the cilium as a structure already present, which is as delicate as the finest structures demonstrated in the cell, it has been the thought of the writer that reagents which produce no change in it would likewise leave the elements in the cell undisturbed, and thus the structures found in the cell could be considered normal.

\section{Methods and Materials.}

Paramecium caudatum, Stylonychia pustulata and Actinosphaerium eichhornii were used. Probably all the cilia of Stylonychia are compound; that is, composed of a number of fibrils coiled together spirally (PI. I, Fig. 1.) For this reason the effect of the reagents on its cilia are more easily observed, and it was used entirely for the 
photographs. Actinosphaerium was chosen because of its long, finely drawn out pseudopods, which have a central core of fibrillae. In taking the records only the fibrillae were considered.

In all, twenty-eight different agents were tested. They represent the killing fluids generally used in cytological studies. For convenience $I$ have arranged them in seven groups according to some one reagent they contain. Some reagents are found in more than one group.

All observations were made under a $1.5 \mathrm{~mm}$. (Spencer Lens Co.) Objective and No. 1 eye-piece.

\section{Osmic Acid Group.}

This group contains osmic acid, 4 per cent., 1 per cent. and 2 per cent.; osmic acid 2 per cent., 95 per cent. alcohol, equal parts; 2 per cent. osmic acid mercuric bichloride saturated in normal salt, equal parts; 2 per cent. osmic acid, 10 per cent. formol, equal parts, and strong and weak Flemming. (If two or more reagents enter into a solution it was made up just before using. This holds for all reagents in all groups.) These reagents prove to be the more satisfactory in preserving cilia than those of any other group. In most cases the cilia are well fixed in nearly normal condition. Strong and weak Flemming are the exceptions.

Osmic acid:-Cilia treated with osmic acid in solutions of .4 per cent., 1 per cent. and 2 per cent. strength seem entirely normal. They are full length and straight. (Pl. I, Fig. 2). After making many tests with the three solutions the author favors the 2 per cent. solution as the most reliable.

Two per cent. osmic, 95 per cent. alcohol:- This combination is a fair killing agent.

Two per cent. osmic + mercuric bichloride:-This solution next to osmic acid gave the best results. Cilia treated with it are full length and straight.

Strong and weak Flemming:-These two solutions so universally used in cytological studies gave the most unsatisfactory results of any in this group. Cilia are apparently broken or twisted into what appears to be short, crinkled threads. (Pl. I, Fig. 3.) These threads 
resemble the mitoms of Flemming, also those so often figured by botanists whenever a fibrillar structure is represented.

Two per cent. osmic + formol:-Cilia treated with this solution are straight and entire. In stylonychia the fibrils seem broken up, but the cilium, as a whole, is well preserved.

\section{Mercuric Bichloride Group.}

Saturated solution of $\mathrm{HgCl}_{2}$ in normal salt, $\mathrm{HgCl}_{2}$ and 2 per cent. osmic acid, equal parts Mann's Fluid, Rabl's Fluid, and $\mathrm{HgCl}+95$ per cent. alcohol. Mercuric bichloride gives better results when used alone than when used in any combination with other agents except osmic acid. In most cases the cilia are twisted, shrunken and broken. $\mathrm{HgCl}$ in combination with alcohol gave the poorest results. Fig. 4, Pl. I, shows a group of cilia killed with Rabl's Fluid. They are typical for the cilia killed with any reagent of this group.

\section{Alcohol Group.}

This group contains besides alcohol absolute, 95 per cent., and 50 per cent. alcohol in combination with $\mathrm{HgCl}_{2}$, osmic acid and acetic acid. Alcohol with the exception of acetic acid gave the most unsatisfactory preparations of all the reagents tested. Cilia were often entirely destroyed. The animal was shrunken and in case of Stylonychia broken up. It was often difficult to find pieces for record. Pl. I, Fig. 5, shows one of the best groups of cilia found after treatment with absolute alcohol. Out of twenty animals only three or four showed any cilia.

\section{Potassium Bichromate Group.}

This agent enters into Müller's, Zenker's and Tellyesniczky's fluids. Cilia treated with these reagents are shortened. In Stylonychia the fibrills are much crinkled and twisted, in $\Lambda$ ctinosphaerium the fibrills are granulated. Zenker's fluid, which is used more than any other of the group, gives the best results, but with it the ends of the cilia are rounded and fused. (Pl. I, Fig. 7.) 


\section{Chromic and Acetic Acid.}

These two agents enter into strong and weak Flemming and the common chromo-acetic acid solution. Chromic acid shrinks and fuses cilia. (P1. I, Fig. 10.) Acetic acid melts them down into a mass of granules. (Pl. I, Figs. 8, 9.) The combination of the two fuse the cilia so that they appear matted. (Pl. I, Fig. 11.) The action of Flemming's solutions has been discussed above.

\section{Picric Acid.}

Picric acid enters into Mann's and Rabl's fluid, which I have placed in the $\mathrm{HgCl}$ group, and is used with acetic acid. Cilia treated with it are fairly well preserved. The ends are fused, but in some cases the fibrils remain quite distinct nearer the base. (Pl. I, Fig. 12.)

\section{Formol.}

Formol in 4 per cent. and 10 per cent. solutions and in a 1 per cent. solution of osmic aeid in 5 per cent. formol was used. It is difficult to interpret the action of this agent. The body of the animal was poorly preserved. In the case of Stylonychia it was broken into fragments. The fibrils of the cilia attached to these fragments seemed well preserved, but the cilia themselves had their identity destroyed. The stronger solution gave the best results. (Pl. I, Tiig. 13.)

\section{Platinum Chloride.}

A 1 per cent. solution of Platinum chloride was tested. It yielded no results to recommend it.

\section{Conclusions.}

Cilia treated with different reagents show a marked difference in structure. Of the twenty-eight agents tested osmic acid (.4 per cent. to 2 per cent.) is the only one that preserves the cilia in normal condidition. Wherever it enters into a killing fluid its influence can be seen. All other reagents produce marked changes in cilia which are characteristic for each reagent.

In interpreting the structures revealed in tissues killed with these reagents their action on fibrillar structures should be taken into 
account. We should not expect the fibrillar structure to remain normal in tissue treated with most of them. Fibrillae in the cell should show the same structure that cilia show after treatment with any one reagent. Thus, osmic acid would leave the fibrillae normal, strong and weak Flemming would break them up into short twisted threads, mercuric bichloride would in some cases leave them almost normal ( $\mathrm{HgCl}$ sat. in normal salt), and in others fuse them so they entirely disappear. Alcohol would break them up in densely granulated masses, acetic acid would leave them more granular than alcohol, chromo-acetic and picric acid would leave them fused masses, while formol would show them as threads.

\section{Structure of Fragella as Demonstrated by Teasinc.}

\section{Introduction.}

'There is almost universal agreement in the literature on the Flagellum that this organ is "Ein homogener dünner Faden, der keinerlei besondere Anhängsel trägt." This is the view of Kunstler, Löffler, Bütschli, Klebs, Hertwig and, more recently, Putter. In 1894 Fischer came forward with the view that a number of flagella, the Flimmergeissel (Euglena viridis and Monas guttula), "Besteht aus einem homogenen Faden, der mit einer oder mehreren Reihen kurzer, dünner, zugespitzter Härchen (Cilien) besetzt ist." On the other hand, another class of Flagella, the "Peitschengeissel," consists of a homogeneous thread that often shows fibrillae clinging to it. So far as I know, Fischer's results have not been confirmed; and my own observations have yielded nothing approaching his figures or descriptions. Putter, because of the structure of the flagellum, rejected the fibrillar theory of the structure of cilia. I hope to show that in its structure is really the best justification for his theory.

\section{Method and Materials.}

For this investigation the flagella of Euglena, Chilomonas paramecium and Spirillum (Sp. ?) were used. Mounts from infusions containing the first two of these forms were placed under a $1.5 \mathrm{~mm}$. oi] immersion and subjected to pressure. 


\section{Euglena.}

The flagellum of Englena is composed of four fibrils which extend its entire length. They are twisted about one another in a spiral of two and one-half turns. (Figs. 1, 2 and 3.) This structure (Pl. II, Figs. 1 and 2 ) is demonstrated with ease by subjecting a flagellum to slight pressure. The fibers gradually untwist or separate so that each is distinctly seen. They can be traced into the animal, where they branch out into a system of rootlets. (Fig. 3.) These fibers probably explain Fischer's thread-like appendages to his "Peitschen-

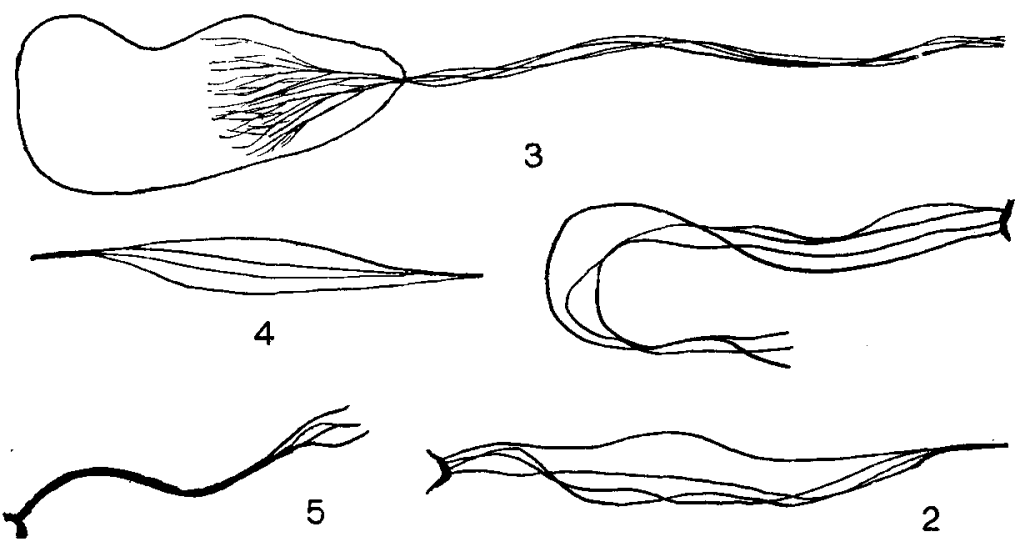

Figs. 1 and 2.--The uncoiled fibrils of the flagella of Euglena.

FIG. 3.-Euglena with the fibrils of the flagellum branching out into a system of rootlets in the protoplasm of the body.

Frgs. 4 and 5.-Flagella of Chilomonas paramecium.

geissel." What he really saw was some of the uncoiled fibers. Although I have used his methods, I have been unable to demonstrate any other structure. I am inclined to think that the fine cilia along the flagellum of Euglena veridis, which he describes, were artifacts. Possibly he may have worked with different species.

\section{Chilomonas Paramecium.}

This form has two flagella, which are much smaller than the flagellum of Euglena. The structure was therefore more difficult to make out. Under the same treatment, however, they were demon- 
strated to consist of four fibrills which had a spiral arrangement. (Fig. 4 and 5.) They were not traced into the cell and their relation to the cell body was not determined.

\section{Spirillum.}

With flagella of bacteria we descend the scale to still more minute forms which are not visible by ordinary histological methods. Still, no question can exist as to their active contractions. Thus, in any tissue cell there may be contractile elements or fibrillae which are invisible by ordinary methods. If simple, single-fibril, cilia or flagella exist, we should expect to find them among these most minute organs of bacteria. It is proposed to derote a special research to this point. At present I am able to offer the evidence from a single type. A large Spirillum common in stagnant water when stained by Loeffler's method shows unmistakably that its long, apparently simple flagellum consists again of four spirally-wound fibrillae. While not demonstrated alive by the teasing method used for Euglena and chilomonas, it is not difficult to find among the stained specimens a complete series from the apparently solid, simple flagellum through all stages of uncoiling to four distinct fibrillae. (Pl. IV, Fig. 8 and Text Fig. 5a.)

\section{Theoretical Considerations.}

As mentioned above, Putter (1903), after a discussion of the fibrillar theory of the structure of cilia, rejected it because of the difficulties met with in applying it to the movements of the flagellum. Parker (1905), in a discussion of the probable structure of cilia, does not agree with Putter and prophesies that even flagella may be fibrillar. From the above observations it is evident that this is true, at least, for three flagella. In these observations Putter's objections to the fibrillar theory become groundless, and the scant attention paid Schäfer's tube theory of ciliary structure is also justified.

Although only three have been demonstrated to be fibrillar, these make it probable that all flagella have a similar structure. The work on cilia to follow proves that they are constructed on the same general plan, though different cilia vary in the number of their component fibrillae. 


\section{Structure of Cilia Demonstrated by Teasing.}

It has long been known that the large cilia of the Hypotrichia (Fig. 6) are composed of many fine fibrils twisted together. In a

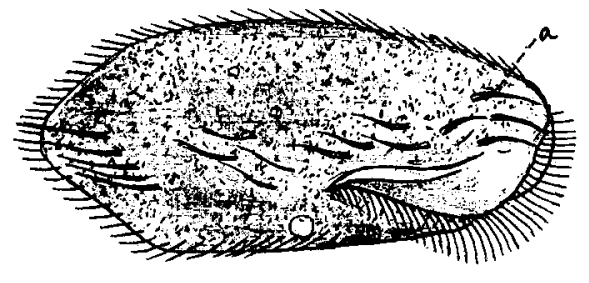

6

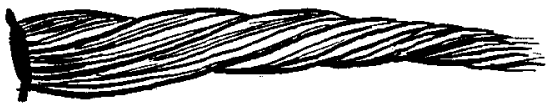

7
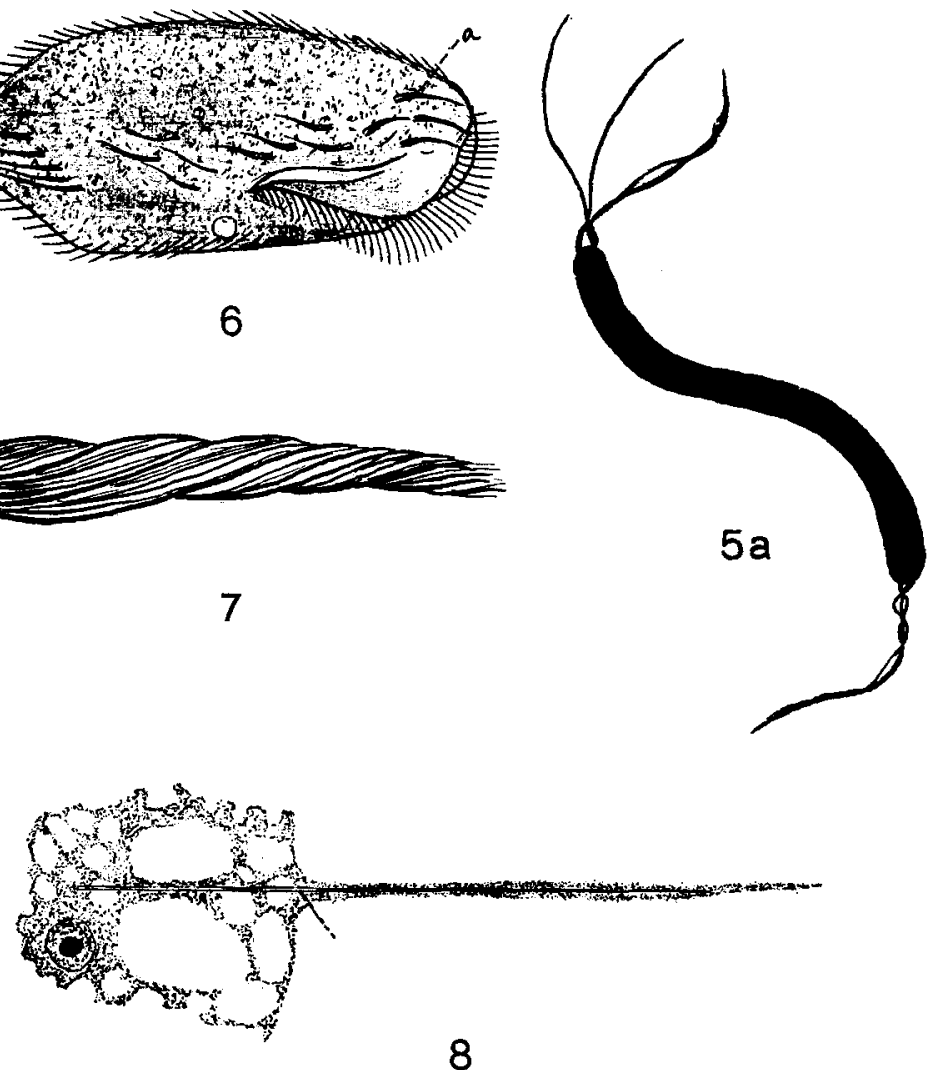

Fig. 5a.-Spirillum drawn from photograph of Plate IV, Fig. 8.

FIa. 6.-Stylonychia showing types of cilia. (From Conn.).

FIg. 7.-A of Fig. 6 much enlarged.

Frg. 8.-Pseudopod of Actinosphaerium Eich. showing axil filament. (From Calkins' Protozoa, p. 80).

study of these forms the author became convinced that all their cilia had a similar structure. Using the same methods which brought out the structure of flagella, the fibrillar nature of these cilia was easily demonstrated. 
The structure of the large cilia (Fig. 7) is that shown in Fig. 3, Pl. II. It is seen that they are composed of a large number of fine fibrils. In life these fibrils are wound together so that the whole appears perfectly homogeneous. In animals subjected to pressure or killed in 2 per cent. osmic acid the separate fibrils appear. In an animal that is breaking to pieces under pressure their fibrillar nature is best seen. (Fig. 6.) All the cilia of the Hypotrichs are made up in a similar way. They are composed of several fibrils which separate under pressure. (Pl. II, Fig. 4.) These cilia vary greatly in size and in the number of fibrils they contain. In many of them it is impossible to distinguish the fibrils that formed each individual after they have become separated. It is only on account of the size and arrangement of the cilia that it is possible to be sure the fibrils are not separate cilia.

The bearing of these observations on the theories of ciliary structure is evident. If in the Hypotrichia we have a series of cilia growing smaller and smaller, all composed of definite fibrils which can be separated, where are we to assume that this fibrillar structure ceases and cilia become homogeneous fibers or tubes of fluid? At the place where we are unable to demonstrate a fibrillar structure? This does not seem reasonable, for our means of demonstrating these structures are by far too gross. The simplest theory is that fibrillar structurs extends on down the scale, although we are unable to demonstrate it. What we know of flagella makes this probable.

\section{Application of Methods to Other Contractile Tissufe. Amoeba.}

The Amoeba has been used by many recent investigators, Buitschli, Berthold, Quincke, Verworn, Rhumbler and others, as the starting point for their studies on contractile protoplasm. Unfortunately, in their investigations they did not apply modern histological technique to demonstrate structure in this form, hence the outcome of their work in microscopical foams, colloidal fluids, etc., as an explanation of amoeboid movement has resulted in widespread confusion in all our theories of protoplasmic structure.

Application of the methods and reagents which give the best prepa- 
rations of cilia show in the Amoeba a definite framework of tissue. This framework is a finely meshed structure, essentially the same for the "endosarc" and "ectosare." It is so woven as to form trabeculae with large inter-trabecular spaces in the interior, and, without essential differentiation, forms the outer (Pl. II, Figs. 5 and 6) membrane, the wall of the contractile vacuole, the walls of all food vacuoles, and the nuclear membrane. This structure is constant in all these relations and cannot be considered an artifact.

In a recent paper, "Locomotion of Amoeba and Allied Forms," the author has shown that the movements of Amoebae in no way correspond to the movements of complex fluids. On the contrary, it is pointed out that Hertwig's contention, that "Das Protoplasma ist kein Gemengsel zweier nicht mischbarer Flüssigkeiten, wie Wasser und Oel, sondern besteht aus einer Verbindung fester, organischer Substanzteilchen mit reichlichem Wasser," holds at every point. In this paper it is suggested that a reticulum of contractile tissue would explain all the facts of amoeboid movement. Since an application of the methods best adapted to preserve cilia, which we know to be contractile tissue, demonstrates a reticulum in Amoebae, and since the presence of a contractile reticulum is the simplest explanation of all the facts of amoeboid movement, I think we are justified in assuming that the reticulum demonstrated is contractile.

In a paper, "Functions and Structures in Amoeba Proteus," Hodge and Dellinger, which is soon to appear from this laboratory, a full report of the work on Amoeba is given, hence this brief reference to the part that bears upon my subject:

\section{Actinosphaerium.}

The literature on the structure of the Heliozoa is extremely limited. Bütschli (1892) speaks briefly of the protoplasm of Actinosphaerium and Actinophyrs. According to him, their protoplasm shows a finelymeshed structure in the ectoplasm, endoplasm and the pseudopods. This structure is not altered in killing with Flemming's fluid, from which he concludes that it is normal. In speaking of the ectoplasm, he says: "After treatment with the osmic mixture already mentioned the meshed structure is everywhere easily recognizable in the ecto- 
sarc. Whether or not the ultimate structure of the axil thread is similar was a point not successfully determined, though it occasionally appeared to be so." The axil thread is the apparently solid core of the pseudopod. According to Calkins (Protozoa, p. 81), this thread is composed of "some unknown substance," which is "Probably stiffened protoplasm similar to the central axis of the reticulate pseudopodia." Fig. 8, taken from Calkin's "Protozoa," shows this axil filament and the surrounding protoplasm according to his view. My own work shows that the filament is really a bundle of fibrils which are probably contractile.

\section{Structure.}

In this investigation Actinosphaerium eichornii was used. Animals killed in 2 per cent. osmic acid and studied in dilute glycerine show a definite reticular network which forms the substance of the trabeculæ that surround the large inter-trabecular spaces. (Pl. II, Fig. 7.) The fibers of the trabeculae often unite to form larger fibers, which in a few cases were traced to the axil filament of the pseudopodia.

That we are dealing with a reticulum and not alveoli, as held by Bütschli, is evident from the following observations. The fibrillae of the pseudopods could in a few cases be traced into the reticulum and evidently furnished some of its fibers. (Pl. II, Fig. 10). Fibrillae could be found that were branching into smaller fibrils, and in these cases alveoli were often found in the angles. (Pl. II, Fig. 9 ; Pl. III, Fig. 1.) Sometimes the angle was completely rounded out by the alveolus. (Pl. II, Fig. 9, and Pl. III, Fig. 4.)

In the course of this investigation an explanation was suggested to me by Dr. Hodge which accounts for all the observations of alveolar protoplasm. It was this: If a viscid fluid bathing a reticulum would tend to form alveoli in the meshes of the reticulum and round out their angles, a perfect alveolar appearance would obtain. That such alveoli do tend to form on the angles is seen in Fig. 1, Pl. III.

Acting on this suggestion, experiments were made to determine to what extent this would hold in oil foams. Silk thread was teased into its ultimate fibers in an oil foam and mounted under a cover 
glass. P1. III, Fig. 2, shows the form the alveoli took. They are seen to be in the angles of the crossed threads, and their general arrangement is governed by the fibers. Another preparation was made in which no threads were placed. Pl. III, Fig. 3, shows the form of the alveoli in this case. Pl. III, Fig. 4, is the protoplasm of Actinosphaerium. It is evident that Figs. 2 and 4 are structurally alike, and one is convinced that there is fibrillar structure present in the protoplasm of Actinosphaerium, which controls the arrangement of the alveoli. The arrangement of alveoli in definite lines was often remarked upon by Bütschli. This definite arrangement finds an explanation in the above observations. Protoplasm, then, may be a mixture of fibrillae with foams, the arrangement of the alveoli being governed by the fibrillae.

So far as I know, there is nothing in this hypothesis that is contradictory to what we know. On the other hand, it would explain the presence of alveoli where a reticulum is demanded. It remains for investigation to show how far this explanation holds good. The above observations tend to strongly support it. In a later section other evidence will be adduced.

Probably more interest attaches to the work on the pseudopods than to that on the body of the animal. As mentioned above, the pseudopod has an axil filament that has generally been supposed to be simply a supporting mechanism. This filament runs through the ectosare and ends near a nucleus in the endosarc. It is usually figured as if it were perfectly homogeneous (Fig. 8), but according to this conception it is difficult to see how it is formed and how, under stimuli, it is drawn into the body.

While studying the pseudopods of Actinosphaerium to determine the effects of different reagents it was noticed that the axil filament was almost always more or less fibrillar. Following out this suggestion, I made a careful study of pseudopodia killed in 2 per cent. osmic acid. By teasing such specimens, the fibrillar nature of the axil thread becomes quite distinct. (Pl. III, Figs. 5, 6, 7, 8.) Although it was difficult to trace the relations of these fibrillae inside the body, examples were found which seemed to indicate that they, in part at least, branch out into the meshwork of the trabeculae. 
(Pl. II, Fig. 10.) These observations are in agreement with those of Bütschli on the psendopodia of Actinophyrs. He says: "The protoplasm of the pseudopodia appeared in part composed of distinct longitudinal fibers. Moreover, this fibrillar modification of the protoplasm could be followed through the coarsely vesicular ectoplasm into the finely meshed endoplasm, and at the same time it could be demonstrated that the fibrous tracts pass into the meshwork of the endosarc."

Whether or not the fibrillae of the pseudopodia and of the body reticulum are contractile was not determined with certainty. However, one set of observations indicates that it is. Throughout the entire series of studies Ehrlich's blood stain in dilute glycerine (one drop of stain to one ce. of 10 per cent. glycerine) was used to stain the tissues. It was found that this stain picked out the contractile stalk of Vorticella, the ciliary bands of Vorticella and Stentor with their cilia, and the fibrillae of smooth and striped muscle. It is admitted that these are the contractile elements in these forms. This same stain picked out the fibrils of the pseudopodia of Actinosphaer. ium and the reticulum of the body, which indicates that we have here, also, contractile tissue.

\section{Stentor.}

The contractile elements of Stentor have been described by a number of writers (Metschnikoff, Johnson and Bütschli). They are easily recognized as the cilia and myonemes in the living animal, but require special methods to demonstrate their nature.

The cilia are of two kinds, those surrounding the peristome, and the body cilia. The former are complex; that is, composed of a large number of delicate fibrils. Pl. IV, Figs. 1 and 2, show the cilia after treatment with osmic acid and strong Flemming. From Pl. IV, Fig. 2, and Text Fig. 9 it is seen that they are extended into the body as an apparently solid mass. The relations or meaning of this part of the cilia were not determined. It is much like the solid ends of the fibrous core of the pseudopods of Actinosphaerium. The finer structure of the body cilia could not be demonstrated, but in many cases of partly melted down cilia they showed every indication 
of being composed of fibrils. However, I am not ready to say that this is the case. It remains to be seen what a more powerful magnification will show.

The myonemes in specimens partially teased and killed in 2 per cent. osmic acid show a definite fibrillar structure after staining with the Ehrlich-glycerine mixture. (Pl. IV, Figs. 3 and 4.) Pl. IV, Fig. 3, which is a small section of a myoneme teased away from the body, indicates that they send branches into the body. Other observations led me to think that is the case. The body cilia are all outgrowths from myonemes. Stentor thus supports the theory that contractile tissue is fibrillar.

$$
\text { Epistylis. }
$$

This form was killed and stained by the same methods as given above. The stain quickly picks out the contractile elements. These are the cilia, the ciliary bands around the peristome and the myonemes which extend from the outer peristomal band to the point of attachment at the stalk. (Fig. 10.) The definiteness with which the stain picks out these structures leaves no doubt as to their identity. The presence of the contractile elements in these positions explain all the movements of the animal.

No data was obtained as to the finer structure of the cilia or the peristomal bands. In a teased specimen the finer structure of the myonemes was demonstrated. They are distinctly fibrillar, as shown in Fig. 11, probably send fibrillae into the body. Their relation to the outer peristomal band is also shown in the above figure. In epistylis the myonemes end at the junction of the body with the non-contractile stalk.

\section{Smooth Muscle.}

The major part of the work on smooth muscle was done by Duncan in this laboratory at the same time I was working with the contractile tissue in other forms. Reference will be made to his paper later. He did not investigate the stalk of vorticella, which is generally recognized as the starting point for investigations on smooth muscle. Although there are two well-established views as to the seat of contractility in the stalks of vorticella, I think there is no doubt that 
the muscle-like spasmoneme is the contractile element. It is picked out immediately by the above Ehrlich-glycerine mixture and, with the myonemes and the cilia, is stained bright red when there is no stain in the rest of the animal.

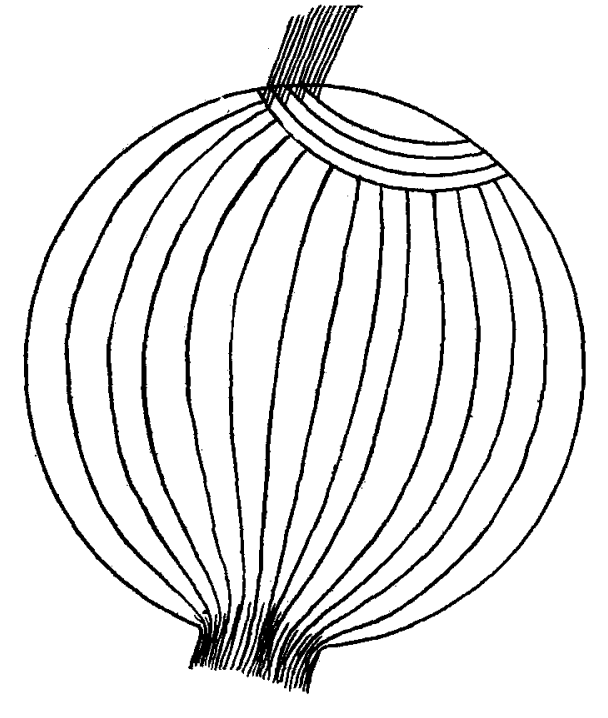

10

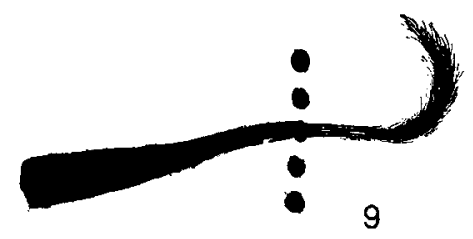

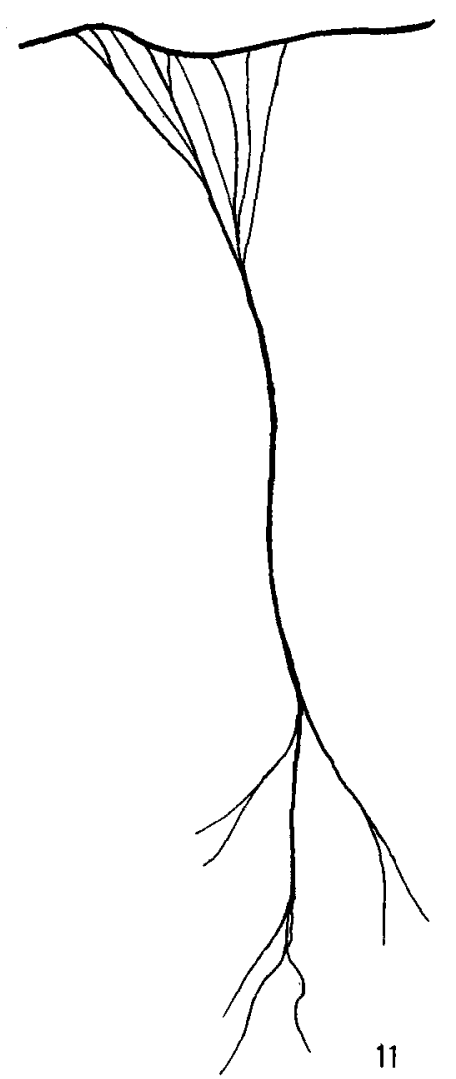

11

Fig. 9.--Oral cilia of Stentor killed in strong Flemming.

FiG. 10.-Contractile elements of Epistylis.

Fia. 11.-Teased Myonome of Epistylis.

No structure could be demonstrated in the spasmoneme itself. Pl. IV, Fig. 6, is a microphotograph taken with an Ultraviolet Microseope. In this photograph the spasmoneme appears perfectly homogeneous; on the other hand, its relation to the myonemes indicates 
that it is fibrillar. It is in reality the continuation of these myonemes into the stalk, and we should expect them to retain their structure, as they retain their function in this position. (Fig. 12.) Although no structure has been demonstrated, I do not think we are justified in assuming that it is homogeneous. It is probable that when a method is found to demonstrate it the structure will be found to be fibrillar.

As mentioned above, the major part of the work on smooth muscle was done by Dr. Dunean in this laboratory, and his results are ready

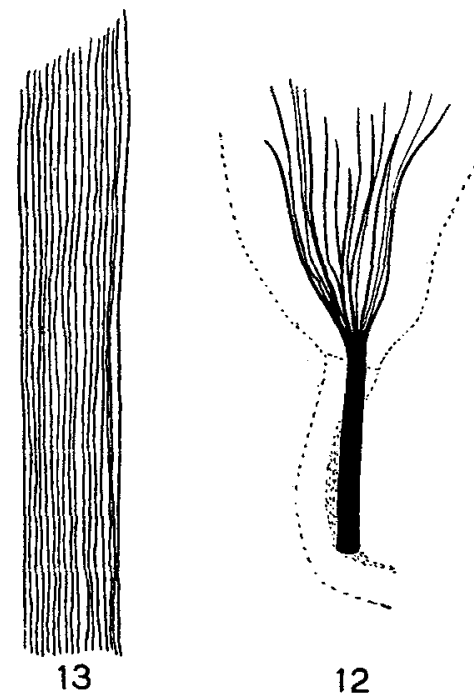

Fra. 12.-Myonomes of Carcesium.

Fic. 13.--Smooth muscle fiber taken from earthworm. (After Duncan.)

for publication. He used the same stain and, in many cases, the same killing reagents that $I$ have used. His results are in agreement with what $I$ have found in my studies. He finds that the smooth muscle in all the places he examined it (Hydra, sea anemone, star fish clam, Tubifex, Lumbricus, and eat) is distinctly fibrillar. Fig. 13, copied from his drawing of the muscle of an earthworm, shows the fibrillar structure in a portion of one of its fibers. The following quotation gives his general conclusions: "All of the structures that we have observed in contractile tissue force upon one the conviction 
that it is composed of fibrillae and interfibrillar substance. However they may have arisen, they are a fact in the structure and not an 'Accident of structure,' as Bütschli maintains. In every case in which I have studied contractile tissue it has been composed of fibrillae or a single fibril running out from a cell."

\section{Discussion of Results.}

Present authorities are perhaps about equally divided on the question of the fibrillar, alveolar or colloidal-fluid nature of contractile protoplasm. In the cilium we have this most interesting substance in not only its purest, but also its simplest form. It is thus the natural point from which to begin the study of its structure; and by taking advantage of the natural path afforded by a comparative series of typical cilia, it seems possible to gain clearer conceptions than those attained through any other line of approach. The general conclusion is that contractile protoplasm is fibrillar in all the forms studied.

The fibrillar structure is preserved in its normal appearance by but few of the ordinary killing reagents. The great majority so alter the fibrillae that they are no longer recognizable. This fact goes far toward explaining the confusion in current ideas of protoplasmic structure. Before we deny fibrillar structure in any tissue we clearly must determine whether the reagent used preserves fibrillae. The beginning which has been made in my investigation of the effects of killing reagents on cilia leads us to conclude that osmic acid alone can be depended upon to preserve fibrillae in their normal appearance. Anyone who will watch cilia dissolve or change into granules during a second's contact with an unfavorable reagent will require no further argument on this point. Naturally, some fibrillae are more resistant than others. Thus, the fibrillae in the pseudopods of Actinosphaerium were left intact by reagents which completely destroy their identity in the cilia of Stylonychia.

A point of special importance is the result gained by teasing flagella fresh under high powers of the microscope. Structures revealed by this method are in no wise open to the criticism that they are artifacts produced by killing reagents. The ease with which the flagella studied are resolved into their component fibrils and the clear- 
ness with which the method demonstrates the fibrillae of the axil filament in the pseudopod of Actinosphaerium leads one to think that this line of approach, or some modification of it, might yield valuable evidence as to the structure of the neurite and axis cylinder of nerve fibers. My observations on flagella and cilia as they pass under different reagents from fibrillar to meshed or granular debris leads us to conclusions as to the action of killing reagents on protoplasm different from those arrived at by Fisher and Hardy. Instead of considering all fibrillar structures as artifacts, it would seem that few investigators have divined the true fibrillar nature of protoplasm, because they have used reagents that destroy or modify the fibrils.

Alveoli exist in protoplasm, but reagents which preserve cilia never yield completely alveolar structures that could possibly be interpreted as Bütschli's "Schäume." The comparison of the alveolar protoplasm of Actinosphaerium, or of any of Bütschli's Schäume, as he figures them, with simple emulsions and with emulsions permeated with delicate fibers, leaves little doubt that the alveoli of protoplasm have their arrangement determined by fibrillae. This compromise interpretation uniting the fibrillar and alveolar theories of the structure of protoplasm has been offered by other writers, and is rather a matter for further investigation than for discussion in this paper.

The resolution of the flagellum of Euglena, Chilomonas and spirillum into four distinct fibrils and the demonstration of the fibrillar structure of the cilia of Stylonychia leaves the way clear for acceptance of not only the fibrillar theory of the structure of cilia, but also for the conception of fibrillae as a component of any protoplasm. With its acceptance, all theories which regard cilia as tubes or complex fluids appear gratuitous complications, and hence untenable.

In cilia or flagella capable of movement in all directions there should be at least four contractile fibrils. I have succeeded in demonstrating these in a typical series of forms. The presence of these four fibrils not fused or cemented together, but coiled in a long spiral, accounts for all their complex movements. Parker ('05) has pointed out that in cilia incapable of reversing only one contractile filament is necessary, if this is attached to an elastic supporting rod. With 
reversible cilia both fibrils must possess the power of contracting, each alternately or under different stimuli, acting as elastic support for the other.

As I have watched and studied cilia and other contractile fibrillae for the past four years, comparing at every step the living with the fixed structure, I have observed many things that cannot be detailed in this paper, but I have seen nothing which contradicts the fibrillar theory of contractile protoplasm. No one who has watched the basal cilia of Vorticella protrude and be absorbed, often within a few seconds, can deny great plasticity to the contractile fibril; but, while it contracts and lashes the water or pulls hard enough to pinch a paramoecium in two, formed it must be, and to think of it as a strand of fluid baffles imagination. No one who has watched an arnoeba divide can deny to the fibrils the power of auto-section or amputation, probably the power to liquefy at certain points; nor can one who has watched a Vorticella attach itself and grow its stalk question that the contractile fibrils have the power to cement themselves to foreign substances, and this, it would seem, must carry the conclusion that they fuse with one another. On the other hand, those who hold that contractile protoplasm is a complex fluid and that all fibrillar structure demonstrated in it is the result of fixing reagents, must explain why a reagent which preserves fibrillae outside the cell might not preserve them within the cell, and also why a reagent that destroys the fibrillae outside might not be expected to change those inside the cell. They must also bring forward a satisfactory explanation for the fibrillae which can be so clearly demonstrated in cilia and flagella of the living cell.

\section{Conclusions.}

1. Osmic acid is a satisfactory fixing reagent for the contractile structures investigated.

2. To interpret structures inside a cell after fixing with any reagent we must take into account alterations produced by it in fibrillar structures outside the cell.

3. Absence of fibrillar structure may mean that the fixing reagent used has destroyed the fibrillae.

4. The cilia of Stylonychia are composed of spirally coiled fibrils; 
and the flagella of Euglena, Chilomonas and Spirillum are composed cf four spiral filaments.

5. The axil filament in the pseudopod of Actinosphaerium is fibrillar.

6. The protoplasm of Actinosphaerium is reticular as well as alveolar. The definite arrangement of alveoli in any protoplasm is probably due to the presence of fibrils.

7. The contractile elements of tissues investigated are in every case fibrillar or reticular.

Clark University, May 31, 1907.

LITERATURE CITED.

Alles, 1903. The early stages of spindle formation in the pollen mother cell of Larix. Ann. of Bot., Vol. 17, p. 281.

ANDREWs, G. F., 1897. Living substance as such: and as organism. Jour. of Morph., Vol. 12, pp. 1-176.

APAтнY, S., 1891. Ueber die Schaumstructur, hauptsächlich bei Muskel- und Nervenfasern. Biolog. Centralblatt, Bd. XI, pp. 78-88.

1891. Kontractile und leitende Primitivfibrillen. Mitt. Zool. Stat. Neapel. Bd. 10.

ARnold, J., 1867. Ein Beitrag zu der feineren Structur der Ganglienzelle. Archiv f. patholog. Anat. Bd. 41, p. 178.

1879. Ueber feinere Structur der Zellen unter normalen und pathologischen Bedingungen. Virchow's Archiv. Bd. 77.

1898. Structur und Architektur der Zellen. Archiv f. M. Anat. Bd. 52, pp. 134-151.

Ballowitz, E., 1886. Zur Lehre von der Struktur der Spermatozoen, Anat. Anzeiger, p. 363 .

Untersuchungen üher die Struktur der Spermatozoen, zugleich ein Beitrag zur Lehre vom feineren Bau der contractilen Elemente. Archir f. M. Anat. Bd. 32, p. 401.

1889. Ueber Verbreitung und Bedeutung feinfaseriger Strukturen in den Geweben und Gewebselementen des tierischen Körpers. Biologisches Centralblatt. Bd. IX, pp. 650-670.

1890. Fibrillare Struktur und Contraktilität. Pflüger's Archiv. Bd. 46 , pp. $433-464$.

DE Bary, H., 1862. Ueber den Bau und das Wesen der Zelle. Flora, pp. 243-251.

1864. Die Mycetozoen. 2 Aufl. Iseipzig.

BENDA, C., 1901. Ceber neue Darstellungsmethoden der Centralkörperchen und die Verwandschaft der Basalkörper der Cilien mit Centralkörperchen. Arch. f. Anat. u. Physiologie. Supplement. Pts. 1-2, pp. 147-157. 
Bernstein, J., 1902. Die Kräfte der Bewegung in der lebenden Substanz. Braunschweig.

Berthold, G., 1886. Studien über Protoplasmamechanik. Leipzig.

BrüCKe, E., 1861. Die Elementarorganismem. Sitzb. d. K. Akad. Wien. Bd. 44. II Abth. pp. 381-407.

1885. Vorlesungen iber Physiologie. Wien.

Brass, A., 1883-4. Biologische Studien. I. Die Organisation der thierischen Zelle. 1. u. 2. Heft. Halle.

Bütschlr, O., 1873. Einiges über Infusorien. Archiv f. Mic. Anat. Bd. 9, p. 658 .

1892. Untersuchungen über mikroscopische Schäume und das Protoplasma. Leipzig.

Galkins, G. N., 1901. The Protozoa. Columbia Univ. Biol. Series, p. 80, New York.

Connoy, J. B., 1884. La Biologie Cellulaire, pp. 169-270, Lierre.

Conklin E. G., 1896. Protoplasmic movement as a factor in differentiation. Biol. Lect. Mar. Biol. Lab. Whoods IIole. Also Science, 1899.

Cien kowsiry, L., 1863. Zur Eutwicklungsgeschichte der Myxomyceten. Jabrb. f. wiss. Botanik. Bd. 3, pp. 325-337.

vas Plasmodium. Ibid., pp. 400-441-

Crato, 1892. Beitrag zur Kenntnis der Plasmastruktur. Ber. d. Deutsch. Bot. Ges.

1895-6. Bau des Protoplasmas, etc. Cohn's Beitrag zur Biologie der Pflanzen.

Davis, B. M., 1904. Studies on the Plant Cell. American Nat., Vol. 38.

DEaEN, A., 1905. Untersuchungen über die kontractile Vakuole und die Wabenstruktur des Protoplasmas. Bot. Ztg. I. Abth. Heft. I. v. II., pp. 160-226.

Delage, Y., 1895. La structure du protoplasme et les théories sur l'hérédité et les grandes problèmes de la biologie generale, pp. 23-33. Paris.

Dellinger, O. P., 1906. Locomotion in Amoebae and allied Forms. The Journal of Experimental Zool., Vol. 3, pp. 337-358.

Drerch, H., 1905. Der Vitalismus als Geschichte und als Lehre. Leipzig.

DuJardin, F., 1835. Sur les Organismes infusorieur's. Anales Scien. Nat,, pp. $343-376$. 1841. Observations sur les Rhizopodes et les infusoires. Paris.

Durcan, F. N. Unpublished. Comparative study of contractile tissues. Work done in Biol. Lab. of Clark University.

Eвевтн, C. J., 1866. Zur Kenntnis des feineren Baues der Flimmerepithelien. Archiv f. patholog. Anat. Bd. 35, pp. 447-8.

Eimer, TH., 1872. Untersuchungen über die Eier der Reptilien. Archiv f. M. Anat. Bd. 8, pp. 226-243. 
Ermer, Th., 1877. Weitere Nachrichten über den Bau des Zellkerns und über Wimperepithelien. Ibid. Bd. 14, pp. 94.

Engelmane, TH. W., 1868. Ueber die Flimmerbewegung. Jena. Zeitschr. f. Naturwiss. Bd. 4, pp. 321-479.

1879. Physiologie der Protoplasma- und Flimmerbewegung. Herman's Handbuch der Physiologie. Bd. I, pp. 344-408.

1880. Zur Anatomie und Physiologie der Flimmerzellen. Pflüger's Archiv. Bd. 23, pp. 505-535.

1881. Ueber den faserigen Bau der kontractilen Substanzen bei besonderer Berücksightigung der glatten und doppelt gestreiften Muskelfasern. Pflüger's Archiv. Bd. 25, pp. 538-565.

Fischer, A., 1894. Ueber die Geisseln einiger Flagellaten.

- Neuer Beitrag zur Kritik der Fixirungsmethoden. Anat. Anzeiger. Bd. 9 , p. 678 ; Bd. 10, p. 769 .

1899. Fixirung, Färbung, und Bau des Protoplasmas. Jena.

1901. Ueber Protoplasmastruktur. Arch. f. Entwickelungsmechauik. Bd. 13.

FlemmiNg, W., 1882. Zellsubstanz, Kern und Zelltheilung. 8 Pl., 424 pp. Leipzig.

Die Zelle. Ergebnisse d. Anat. u. Entwickelungsgeschichte. Bd. 1, pp. 42-82, 1892 ; Bd. 2, pp. 37-82, 1893; Bd. 4, pp. 355-448, 1895. Bd. 5, pp. 233-328, 1896 ; Bd. 6, p. 184-277.

Gurwirsch, A., 1901. Studien über Flimmerzellen. Archiv f. M. Anat, Vol. 57, p. 184.

1904. Morphologie und Biologie der Zelle, pp. 317. Jena.

HaEckel, E., 1862. Die Radiolarien. Berlin.

Heidenharn, M., 1899-1901. Struktur der kontractilen Materie. Merkel and Bonnet's Ergebnisse. Bd. 8, pp. 3-111 and Bd. 10, pp. 115214.

Hardy, W. B., Structure of Cell Protoplasm. Jour. of Physiology. Vol. 24, pp. 159-208.

Hartmann, E., 1906. Das Problem des Lebens.

HeitzmanN, J., 1873. Untersuchungen über das Protoplasma. I. Bau des Protoplasmas. Sitzber. der K. Akad. d. Wiss. Wien. Bd. 67, Abth. 3.

Hermann, L., 1879. Allgemeine Muskelphysik. Herman's Handbuch der Physiologie.

Hertwig, O., 1892. Die Zelle und die Gewebe. Jena.

HоOKe, RoвERT, 1865. Micrographia, or some physiological descriptions of minute bodies by magnif. glasses, etc.

Jennings, M. S., 1904. Contributions to the study of the behavior of lower organisms. Carnegie Inst. Washington, pp 129-230.

Jensen, PaUl, 1901. Untersuchungen über Protoplasmamechanik. Pflüger's Archiv. Bd. 87, pp. 361-417. 
Jensen, Paul, 1902. Die Protoplasmabewegung. Asher and Spiro. Ergebnisse der Physiologie. Bd. 1, No. 2.

Jensen, O., 1887. Untersuchungen über die Samenkörper der Säugethiere. Arch. f. M. A. Bd. 30.

Kassowitz, MAX, 1899. Allgemeine Biologie. Wien. Bd. 1, p. 134.

KLEIN, E., 1878. Observations on the Structure of Cells and Nuclei. Part I, Quart. Jour. Micr. Sc. (N. S.), Vol. 18, pp. 315-339, Pl. 16. Part II, ibid., Vol. 19, pp. 125-175, Pl. 7.

- On the Grauular Epithelium and Division of Nuclei in the Skin of the Newt. Ibid., p. 477, Pl. 18.

Kleinenbera, N., 1886. Die Entstehung des Annelids aus der Larve von Lepadorhynchus. Zeitschr. f. wissen. Zool. Bd. 44, pp. 1-228.

Kühne, W., 1864. Unters. über das Protoplasma u. die Contractilität. Leipzig.

Kunstler, J., ANd Gunste, CH., 1906. Structure Fibrillaire chez les Bacteriae. C. R. Acad. Sc. T. 143, pp. 84-87.

LokB, J., 1906. Vorlesungen über die Dynamik der Lebenserscheinungen. Leipzig.

Meves, Fr., Struktur und Histogenese der Spermien. Ergebnisse d. Anat. u. Entwickelungsgeschichte. Bd. 11, pp. 437-516. 1897. Ueber Struktur und Histogenese des Samenfadens von Salamander. A. f. M. A. Bd. 50 .

Meyen, Neues System der Pflanzenphysiologie, Vol. I, 1837; Vol. II, 1838; Vol. III, 1839.

Monl, Hugo von, 1846. Ueber die Safthewegung im Innern der Zellen. Bot. Zeitung, p. 73.

Nakgeli, K., 1849. Zeitschrift für wissenschaftliche Botanik. Heft. I-IV. Zürich, 1844-1846.

Gattungen einzelliger Algen. Zürich.

Theorie des Micelles, im Sitzungsb. d. k. bayer. Akad. d. Wiss. zu München, 1862 and 1864.

Nussbaum, 1877. Ein Beitrag zur Lehre von der Flimmerbewegung. Arch. f. M. Anat. Bd. 14 .

ProwazeK, S., Protozcenstudien II. Arb. aus d. Zool. Inst. d. Uni. Wien. Bd. 12, p.

PARKre, G. H., The Reversal of Ciliary Movements in Metazoans. Amer. Jour. of Physiology, Vol, XIII, No. 1, pp. 1-16.

Penard, Eug., 1902. Faune Rhizopodique du bassin du Léman. Geneva.

RABL, C., 1889. Ueber Zelltheilung. Anat. Anzeiger. Bd. 4, pp. 21-30.

Reichert, R. B., 1841. Berichte über d. Fortsch. d. Mik. Anat. in d. Jahr. 1839 u. 1848. Müller's Archiv, p. 162.

Reinke, J., 1905. Die Welt als Tat. Berlin. 
RHUMbLeR, L., 1896. Versuch zu einer mechanischen Erklärung der indirecten Kern- und Zelltheilung. Arch. f. Entwickelungsmechanik. Bd. 3 , H. 4 .

1895. Beiträge zur Kenntnis des Rhizopoden (Beitr. III, IV, V). Zeitschr. f. Wiss. Zool. Bd. 61.

1898. Physikalische Analyse von Lebenserscheinungen der Zelle. Archiv f. Entwickelungsmechanik der Zelle. Bd. 7, pp. 103-350. Allgemeine Zellmechanik in Merkel and Bonnet. Ergebnisse der Anat. u. Entwickelungsgeschichte, Vol. 8, pp. 543-625.

1902. Der Aggregatzustand und die physikalischen Besonderheiten des lebenden Zellinhalts. Zeitsc. f. allg. Physiologie. Bd. I, pp. 279-388.

1904. Zellenmechanik und Zellenleben, p. 43. Leipzig.

1905. Zur Theorie der Oberflächenkräfte der Amoebas. Z. f. wiss. Zool. Bd. 83, pp. 1-52. Bost. Soc. of Nat. Hist.

Schaefer, E., 1891. On the Structure of Amoeboid Protoplasm. Proc. $R$. Soc., Vol. 49, pp. 193-198.

- 1904. Theories of Ciliary Movement. Anat. Anz. Bd. 24, pp. $497-511$.

SoHENK, Fr., 1897. Kritische und experimentelle Beiträge zur Lehre von der Protoplasmabewegung und Kontraktion. Pflüger's Arch. Bd. 66, pp. 247-284.

1900. Ueber den Aggregatzustand der lebendigen Substanz, besonders des Muskels. Pflüger's Arch. Bd. 81.

Schuerden, M. J., 1838. Beiträge zur Phytogenesis. Müller's Archiv, pp. $137-176$.

Sch NeIDER, K. C., 1905. Protoplasmastruktur und Bewegung an Protozoen und Pflanzenzellen. 1903. Vitalismus. Leipzig and Wien.

Schultz, M., 1854. Ueber den Organismus der Polythalamien, etc., Leipzig.

1861. Ueber Muskelkörperchen und das was man eine Zelle zu nennen habe. Arch. de Reich. und du Bois-Reym.

1863. Protoplasma der Rhizopoden. Leipzig.

Schuberg, A., 1891. Zur Kenntniss des Stentor coeruleus. Zool. Jahrb. Bd. 4, pp. 197-238.

SchwaNN, TH., 1839. Mikroskopische Untersuch, über die Uebereinst, in der Struktur und das Wachstum der Tiere und der Pflanzen. Berlin.

SMITH, G., 1906. The Eyes of Certain Pulmonate Gasteropods with Special Reference to the Neurofibrillae of Limax maximus. From the Bull. o. M. C. Zool., Vol. 58, p. 233.

Stmvens, 1901. Studies on ciliate infusoria. Proc. of the Cal. Acad. of Sc., 3 series, Zool., Vol. 3.

Strassburger, E., 1907. Die Ontogenie der Zelle seit 1875. In Progressus Rei Botanicae, Jena, pp. 1-138. 
Strasburger, E., 1892. Schwarmsporen, Gameten, pflanzenlichen Spermato. zoiden, Hist. Beitr. 4, 49.

STRICKER, 1890. Reticular Structure in White Blood Corpuscles. Wiener Med. Jahrb., 1890.

STtuakT, A., 1867. Ueber die Flimmerbewegung. Zeitschr. f. Rationelle Med. Bd. 29.

Valentine, M., 1892. Flimmerbewegung. In Wagner's Handwörterbuch der Physiologie. Bd. I, pp. 484-576.

Verworn, M., 1892. Iebendige Substanz. Jena.

1892. Die Bewegung der Lelendigen Substanz. Jena.

- 1890. Studien zur Physiologie der Flimmerbewegung. Pflüger's Archiv. Bd. 48, pp. 149-180.

1903. Die Biogenbypothese. Jena, pp. 1-114.

Vignon, P., 1901. Recherches de Cytologie gênêrale sur les Epitheliums. Arch. De Zool. Exp. et Gen. Series III. T. IX, pp. 371-715.

Williams, I. W., 1907. The Structure of Cilia, Especially in Gastropods. The American Naturalist, Vol. 41, pp. 545-551.

Wirson, E. B., 1904. The cell in development and inheritance. New York. 1898. The Structure of Protoplasm. Biol. lectures from Marine Biological Laboratory at Wood's Hole, pD. 1-20. 


\section{DESCRIPTION OF PLATES.}

Plates I, II, IIr, and IV are photographs taken with Spencer Lens $1.5 \mathrm{~mm}$. objective and No. 3 eyepiece.

\section{PIATE I.}

Fig. 1 to 13 Cilia of Stylonychia.

Fig. 1 and 2.-Cilia killed with 2 per cent. cosmic acid.

Frg. 3.-Cilia killed with Strong Flemming.

Fia. 4.-Cilia killed with Rabl's fluid.

Fra. 5.-Citia killed with Absolute alcohol.

Fia. 6.-Cilia killed with Tellyesniczky's fluid.

Frg. 7.-Cilia killed with Zenker's fluid.

Fras. 8 and 9.-Cilia killed with Acetic acid.

Fig. 10.-Cilia killed with Chromic acid.

Fra. 11.-Cilia killed with Chromo-acetic acid.

Frg. 12.-Cilia killed with Picric acid.

FIG. 13.-Cilia killed with Formol. 
THE CILIUM.

PLATE I

o. P. Dellinger.

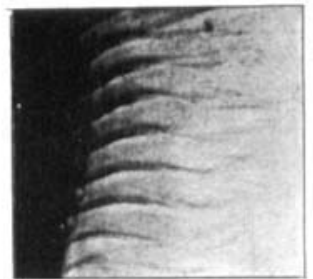

1

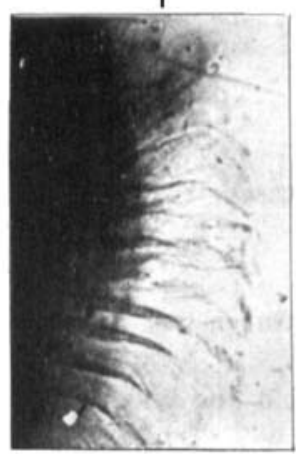

4

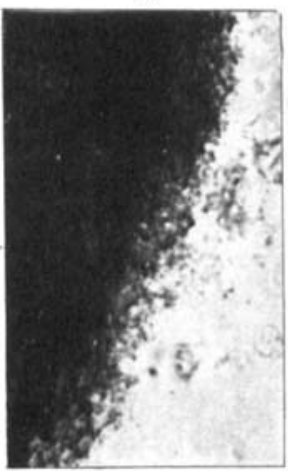

8

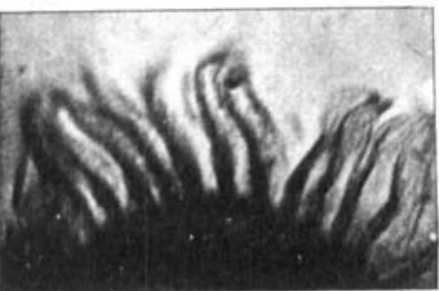

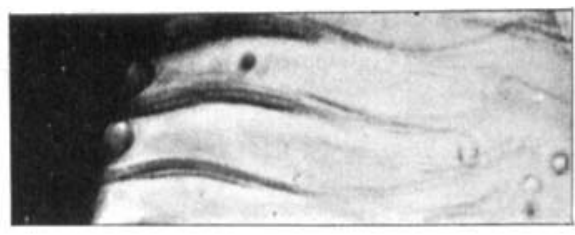

2

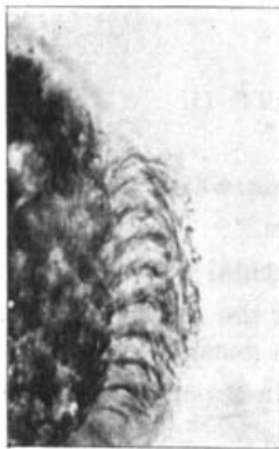

5

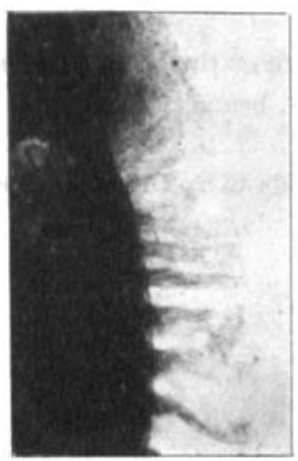

9

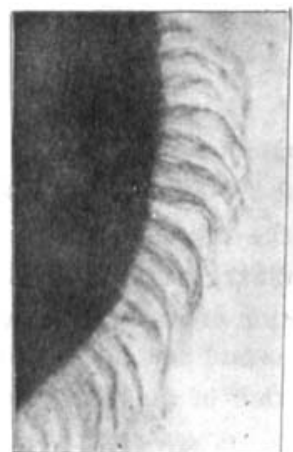

6

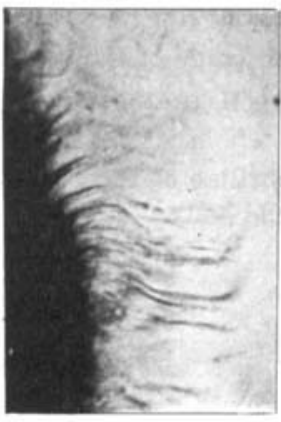

10

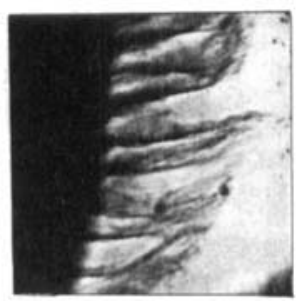

3
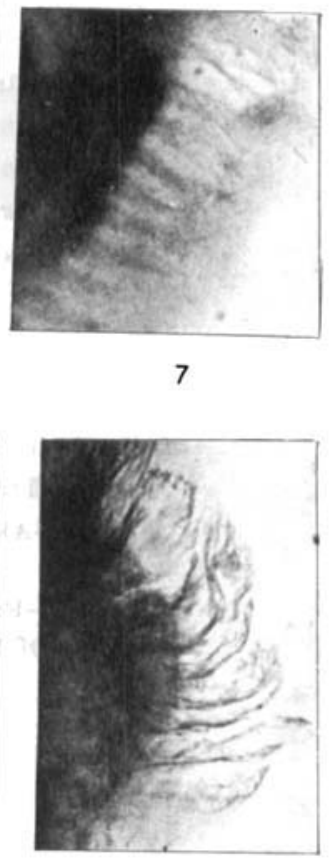

11

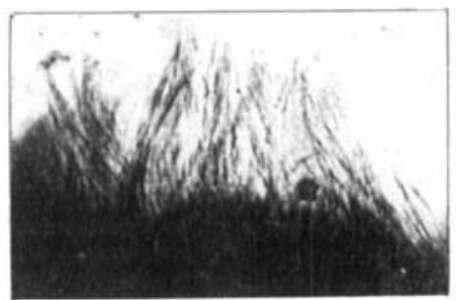




\section{PLATE II.}

F'IG. 1.-Flagellum of Ruglena.

Fras. 1a and 2.-Flagella of Euglena which have been teased.

Fig. 3.-Large cilia of Stylonychia.

FIG. 4.-Ordinary cilia of Stylonychia.

Fig. 5.-Section of Amoeba showing the reticulum of the trabeculae. Killed in 2 per cent. osmic acid. Stained in gentian violet.

Fug. 6.-Portion of amoeba killed in 2 per cent. osmic acid and stained in gentian violet.

Fra. 7.-Small part of a section of Actinosphaerium showing the reticulum of the trabeculae.

Fia. 8.--Trabeculae of the reticulum of the "ectosarc" of Actinosphaerium.

Fra. 9.-Alveoli in the angles of branched fibrillae. From Actinosphaerium.

Fig. 10.-Fibrillae of the pseudopods of Actinosphaerium branching into the reticulum of the body. 
THE CILIUM.

PLATE II.

o. P. DELLINGER.
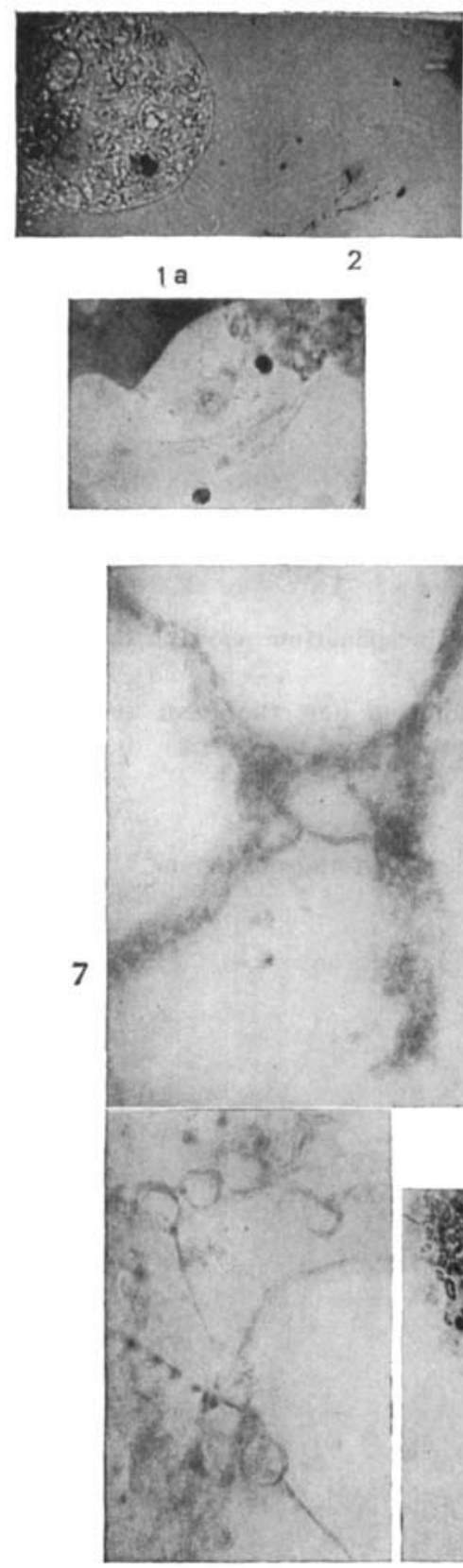

9

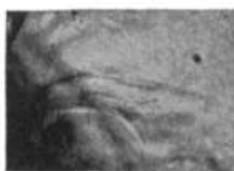

3

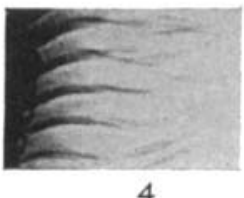

4

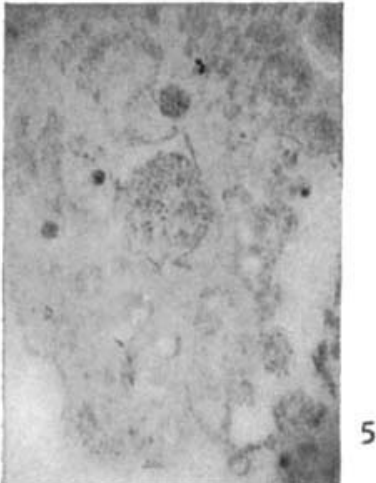

5
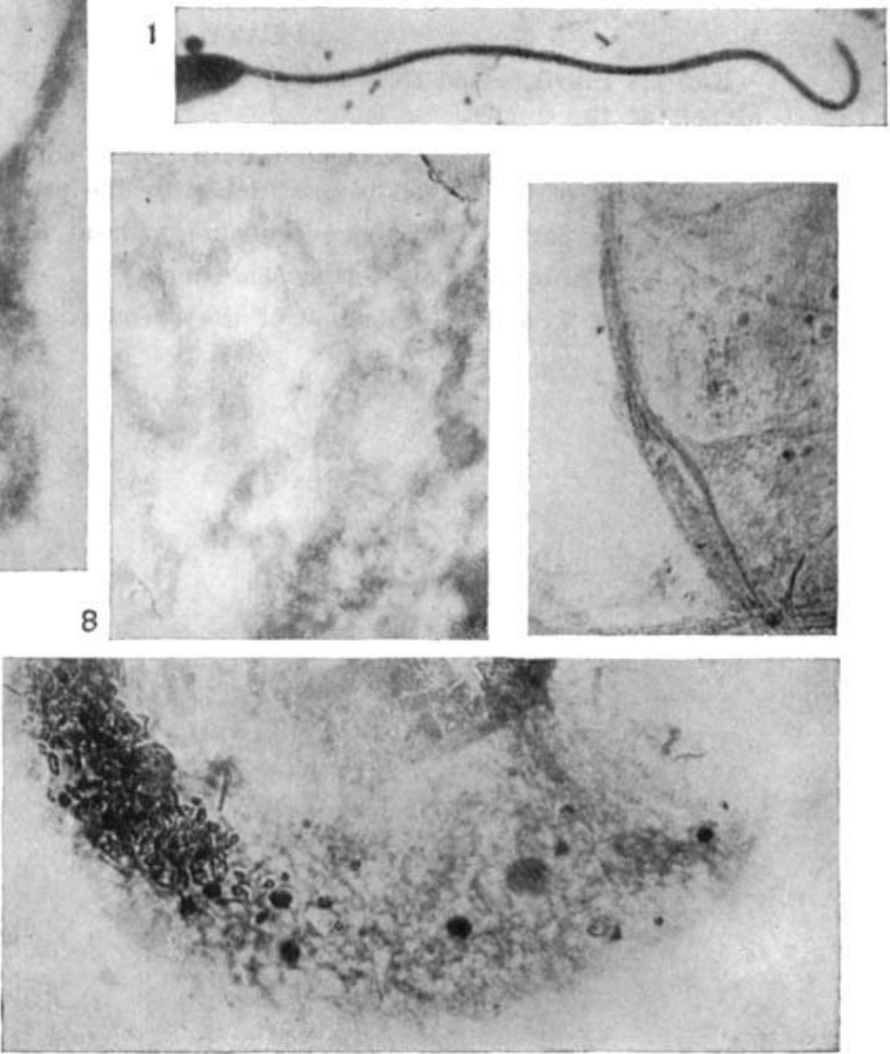

6 


\section{PLATE III.}

Frg. 1.-Fibril teased from the protoplasm of Actinosphaerium showing the alveoli at the angles.

Fig. 2.-All emuision permeated with fibrils showing how the form and arrangement of the alveoli is conditioned by the presence of the fibers.

Fio. 3.-A part of the above emulsion without fibers.

Fig. 4.-Protoplasm of Actinosphaerium.

Figs. 5, 6, 7, and 8.-Fibrillae of the psendopods of Actinosphaerium. 
TH E CIIU M.

PLATE III.

o. P. DELLINGer.

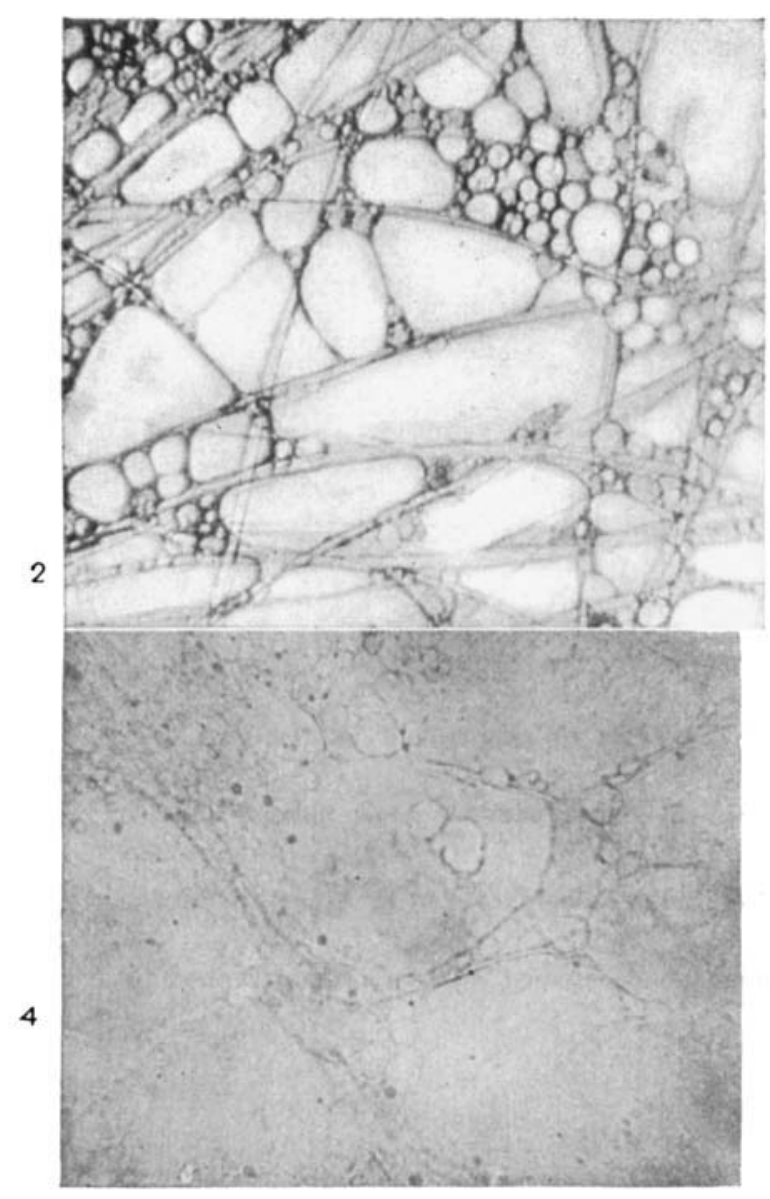

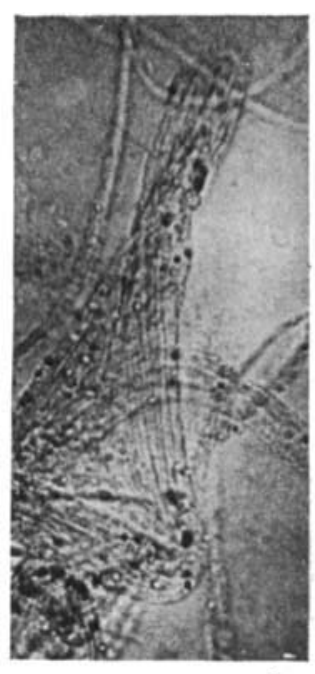

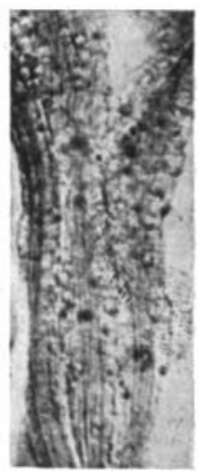

6

5


1

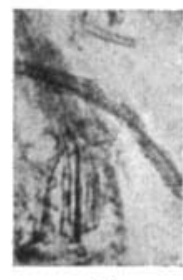

7

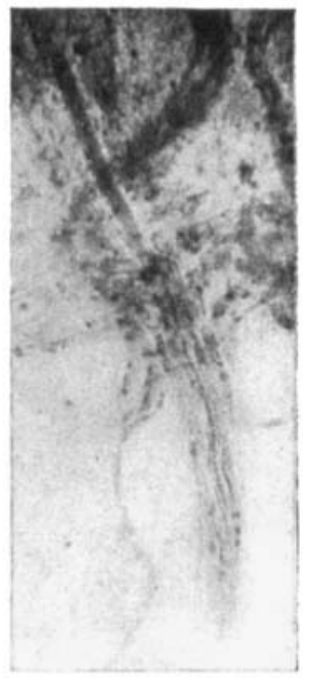

8

3

The Journal of MorfHologx.-VoL. XX, No. 2. 
PLATE IV.

Fig. 1.-Oral cilia of Stentor.

Fic. 2.-Section of stentor at the point of attachment of the oral cilia showing their attachment to the body.

Fra. 3 and 4.-Teased myonemes of stentor showing their fibrillar nature.

FIs. 5.-Myonomes of Stentor.

Fia. 6.-Contractile stalk of Vorticella. Photographed by Dr. C. F. Hodge with Ultraviolet microscope.

Fig. 7.-Ultraviolet microphotograph of striped muscle. Photographed by Dr. C. F. Hodge. 
THE CILIUM.

o. P. DELLINGER.

PLA'TE IV.
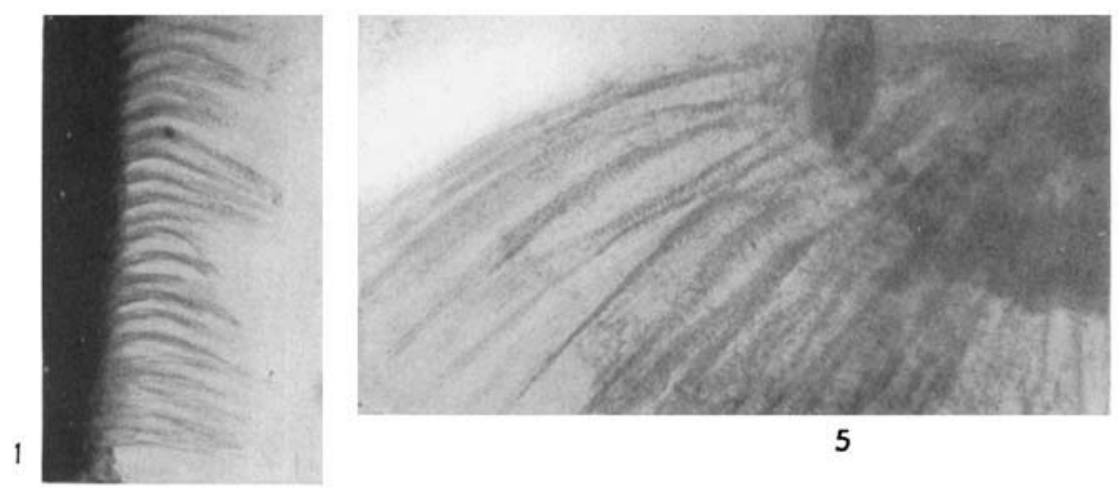

5

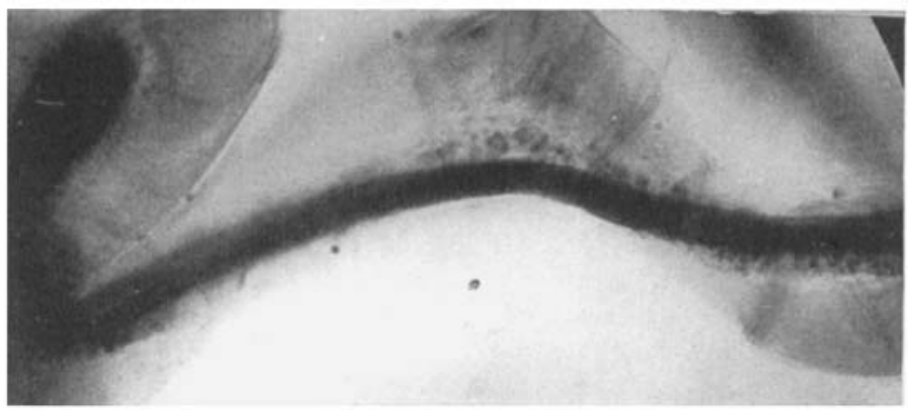

6
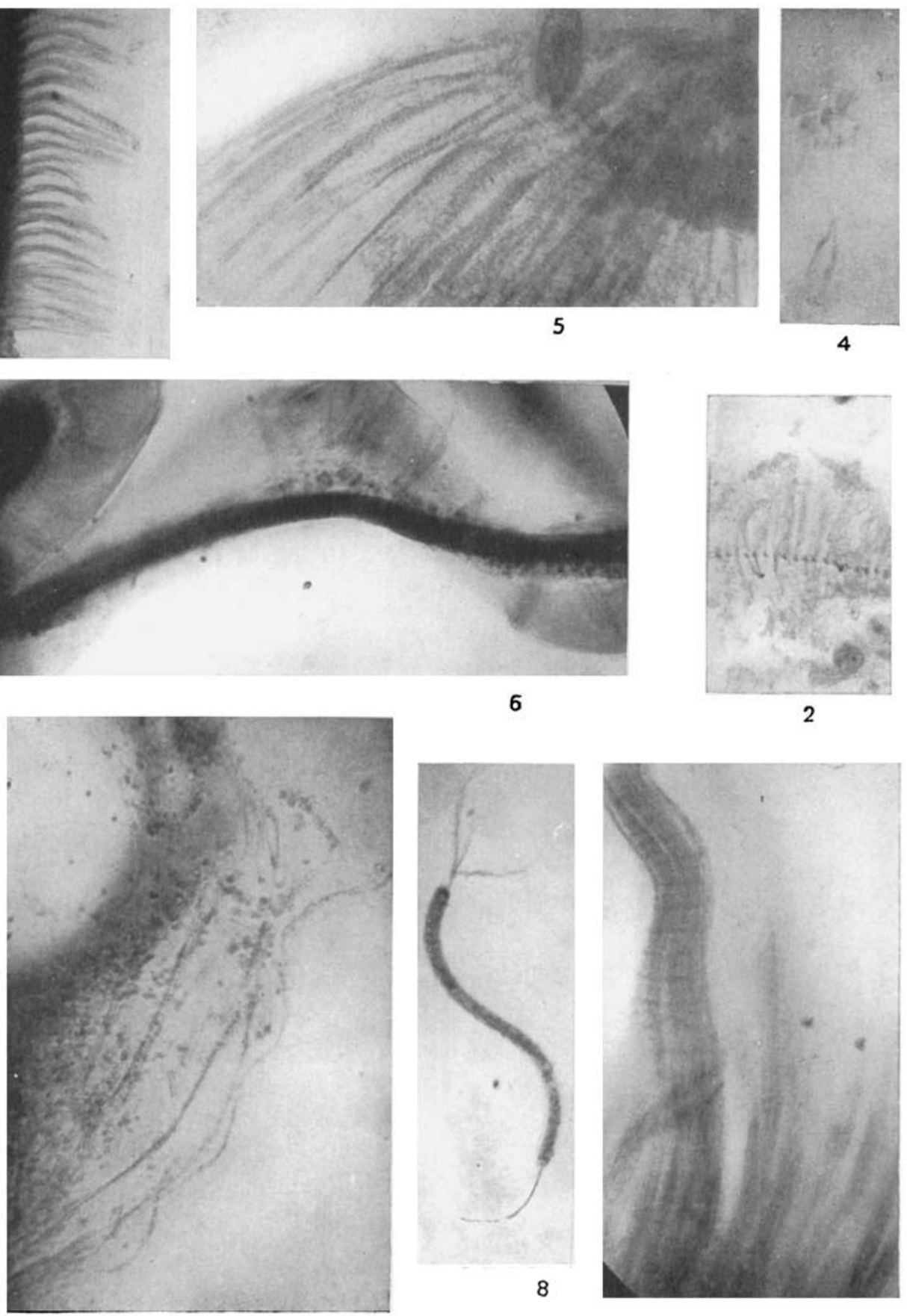

3
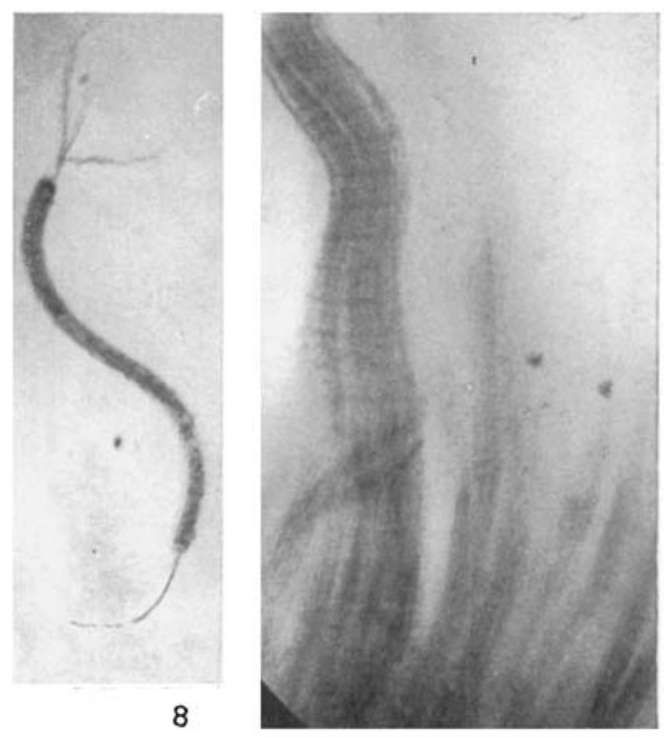

7

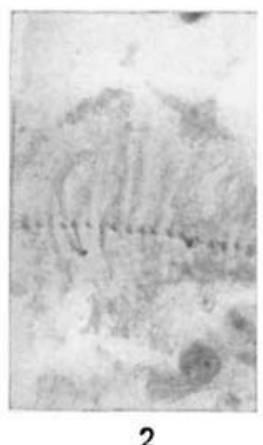

2 